\title{
Floristic Inventory of Woody Species in the Manengouba Mountain Forest, Cameroon
}

\author{
Emmanuel Noumi \\ Dept of Biological Science, Higher Teachers' Training College \\ University of Yaoundé I, P.O.Box 47 Yaoundé, Cameroon
}

Tel: 237-7797-7371_E-mail: noumikap@yahoo.fr

Received: May 18, 2013 Accepted: June 3, 2013

doi:10.5296/jbls.v4i2.4014 URL: http://dx.doi.org/10.5296/jbls.v4i2.4014

\begin{abstract}
This study aims to assess the vegetation structure and diversity of woody species in the mountain forest of mount Manengouba, and compare the values obtained with those from other tropical regions of the world.

A quantitative inventory of a 1-ha plot was achieved by plots of rectangles taking into account all trees whose diameter at breast height $(\mathrm{DBH})$ was superior or equal to $10 \mathrm{~cm}$, and the parameters of floristic diversity were calculated using the standard methodology.

A total of 763 trees, belonging to 40 species, were inventoried. The total basal area was 61.6 $\mathrm{m}^{2} /$ ha.. Most of trees had between 10 and $15 \mathrm{~m}$ height and diameters between 10 and $20 \mathrm{~cm}$, but an important number of individuals attained even higher values, up to $25 \mathrm{~m}$ height and $115 \mathrm{~cm}$ of diameter. The 4 most important families in terms of density, diversity and dominance were Rubiaceae, Euphorbiaceae, Araliaceae and Myrsinaceae. They represent $70.8 \%$ of the Family Importance Value (FIV). The specific composition reveals that a small number of common species dominate the forest, $15 \%$ of species represent $54.59 \%$ of the Index of Value Importance (IVI). They are Macaranga occidentalis, Rapanea melanophloeos, Maesa lanceolata, Polyscias fulva, Psydrax arnoldianu and Rothmannia urcelliformis. A fraction of species $(32.5 \%)$ is only represented by 1 individual.

In conclusion, in the Manengouba montane forest the diversity is weak, the density and dominance are in the higher fringes of the values obtained in most forests of tropical regions of the world. The family Rubiaceae displaced the family Leguminosae in the Manengouba forest even though the Leguminosae is the most important family in the lower and sub mountain forests of the tropical regions of the world.
\end{abstract}


Keywords: Cameroon, Manengouba Mountain, Mountain rainforest, Diversity, Woody flora.

\section{Introduction}

The limit of the guinea-Congolese and Afro highlander regions is situated between 1800-2200 $\mathrm{m}$ (Letouzey, 1985). One notes that the Cameroonian mountains, with the specific example of mount Manengouba (2396 m), form an archipelago connected comfortably (in the floristic point of view), to the other archipelago highlanders of oriental Africa and southern Africa (White, 1983). All these archipelagos include preferential taxa, to the echelon of the family or the species.

Many works on the structure and biodiversity have been achieved in forests of low and middle altitudes in African, Malagasy and Neotropical regions (Villanueva, 1991; Spichiger et al., 1992, 1996; Lejoly, 1995; Rabevohitra et al., 1996; Sonke, 1998; Collin, 1998; Rakotomalaza and Messmer, 1999; D’Amigo and Gautier, 2000; Senterre et al., 2004; Senterre, 2005). They enabled the circumscription of quantitative values for the families and the species of these types of forest. The mountain forests haven't had such investigations conducted according to similar methodologies. Will the characteristic values of the structure and diversity parameters determined in the mountain Manengouba forest permit establishment of differences between her and the forests of low and medium African, Malagasy and neotropical altitudes, or to unite them in the same wholes?

This survey was done on the Manengouba mount, towards the side of Mbouroukou, at 2000-2200 m of altitude. Vegetation is disrupted by the surrounding populations. The stem barks of Prunus africana are removed for example regularly for medicinal uses, an inconvinence that drags many precocious trees and bushes to mortality. The herds of beef (of the Bororos) that graze in the highlander prairie disrupt vegetation by their stampings. The species introduced (Persea americana for example) integrate to the autochthonous flora. This human activity also orders this survey, before a more advanced disruption.

Aims and objectives: The present study was aimed to make a sampling of the Manengouba forest by summaries of plots, taking into account the trees in DBH (Diameter at Breast Height) $>10 \mathrm{~cm}$, to establish their structural and diversity parameters quantitatively, and to characterize the Manengouba forest in relation with the data (already established) of the low and medium altitude forests.

\section{Study Area}

The Manengouba massif regroups in altitude a set of summits, the most elevated, Eboga peak, culminating to $2396 \mathrm{~m}$ (Figure 1). It spreads between $4^{\circ} 48^{\prime}-5^{\circ} 06^{\prime}$ of the North latitude and $9^{\circ} 46^{\prime}-9^{\circ} 55^{\prime}$ of the East longitude. Its planimetric surface is of about 16875 ha. Its flanks are occupied by four villages: Mouanguel (North side), Mouandong (Southwesterly side), Mbouroukou (Northeast side) and Bangem on the (West side). The mount is a volcano-tectonic horst (Deruelle et al., 1991) with irregular shapes. The geology of the summit is essentially constituted of the basaltic volcanic formations, giving a ferralitic soil (Kagou, 1998). The summit presents 3 crater lakes: the man's lake, the woman's lake and the child's lake. The forest covered the south side of the summit. The herbaceous is essentially constituted of an uniform 


\section{Macrothink}

carpet of Sporobolus africanus, and serves for grazing. Many tributaries that leave from the mount give regular rivers either a profile of dendritic or treelike type. They form Dibombé, Djoubé and Jidé on the north side; Maa, Mom, Nguédi and Nhé on the northeast side, Moum on the east side and Mbé on the northwest side. Sources of mineral water exist to the foot of the Manengouba mount in Bangem, Baré, Ngol and Nsoung. In the absence of the data on the local climate of the Manengouba massif, those of Nkongsamba town (900 m of altitude) situated of the north side of the mount are taken into consideration. The annual average of precipitations is $2742 \mathrm{~mm}$ in Nkongsamba (140 km from the Atlantic coast). The level of the rainfalls is influenced negatively by the continentality. The months of December and January are least rainy. The rainfall on the Manengouba mount would be greater to the one of Nkongsamba because of the altitude. The yearly mean temperature is $22.5^{\circ} \mathrm{C}$. The relative humidity rises along the year (above $86 \%$ ). The population is formed by the Mbo (natives), the Bamiléké (emigrants and planters of coffee, Coffea robusta) and of the Bororo (nomads and shepherds of the cows). 

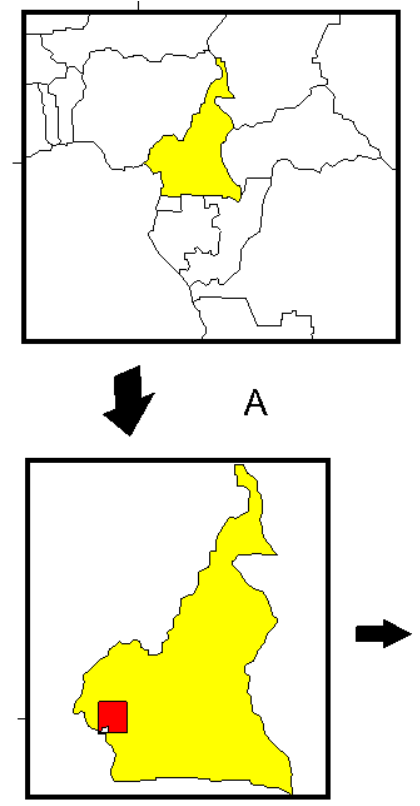

B
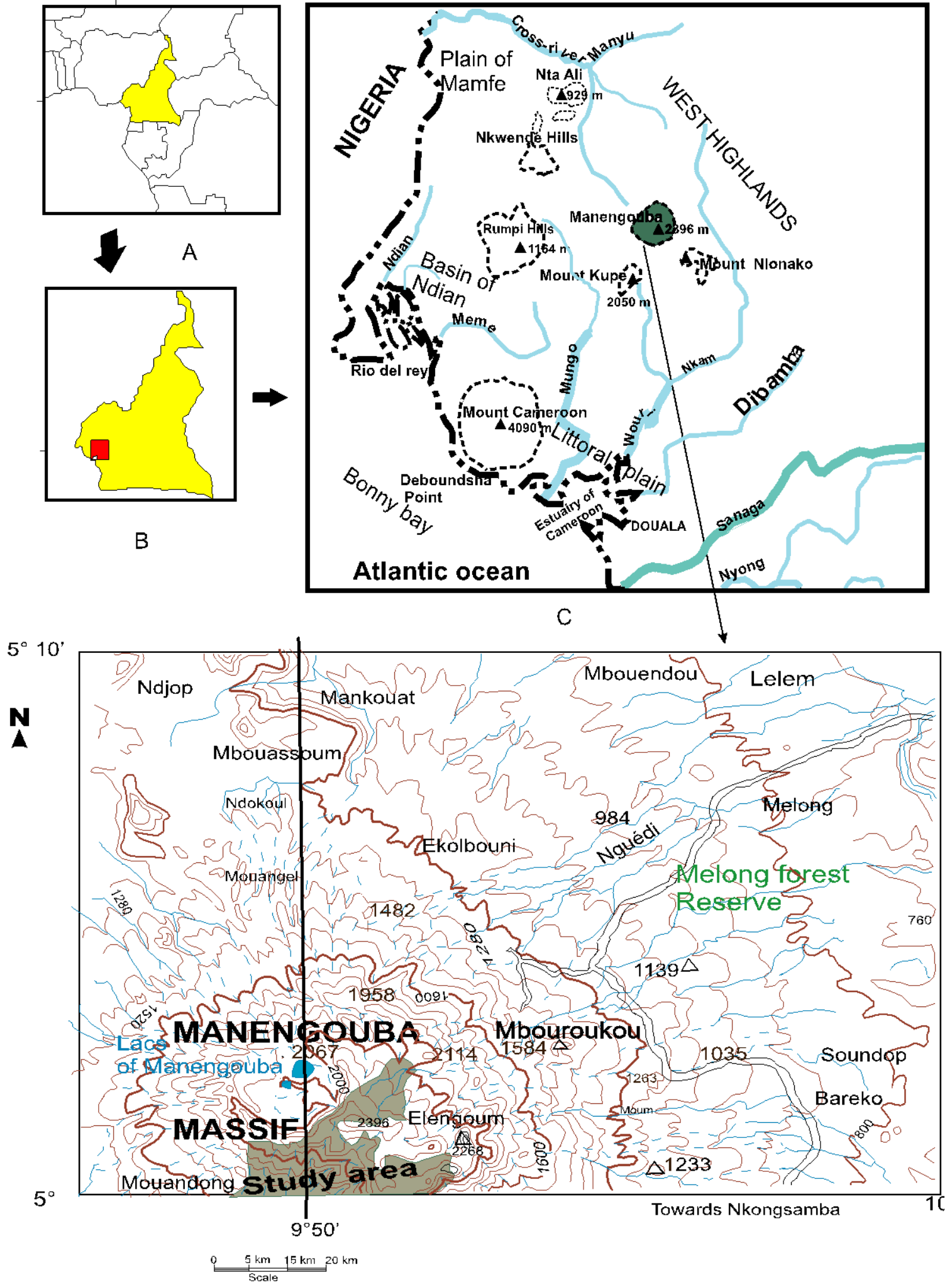

Figure 1. Geographic situation of the Manengouba mountain $(2396 \mathrm{~m})$ on the map of Cameroon. A) Situation of Cameroon on the Africa map, in the gulf of guinea (yellow color).

B) Situation of the Cameroonian Afro-highlander archipelagos in the south West region of Cameroun (red square). C) Some higher summits of archipelago, the highest being Mount 
Cameroon, in the vicinity of Atlantic Ocean. The rivers of the Atlantic basin are in blue color (source: Yahmed and Houstin, 2006). D) Situation of Manengouba forest (grey color) around the highest summit called Eboga peak, culminating to 2396 m, on the South, West and North sides. The site of survey is the forest above $2000 \mathrm{~m}$ of altitude. Sources: map of Cameroon, 1/200000, sheet NB-32-XI, CGN.

\section{Materials and Method}

The fieldworks were made in 2008-2010. The studied forest occupies the Southern, Western and northern slopes of the summit of the Manengouba massif. The sites inventoried, at elevations ranging from 2000 to $2200 \mathrm{~m}$ aslant in the montane forests, were upper $5^{\circ} \mathrm{N}$ Latitude and strading $9^{\circ} 50^{\prime} E$ Longitude) for the plots. Woody plant diversity was assessed in 10 rectangles plots of 0.1 ha dimension, selected on the basis of random sampling of 0.1 ha area. These plots are all identical at the mesological and physionomical point of view. The prospection was made on a rectangular strip of $25 \mathrm{~m}$ of width and $40 \mathrm{~m}$ of length. A trail of 40 $\mathrm{m}$ to the center of rectangle facilitated $12.5 \mathrm{~m}$ sampling on one side and the other side of the trail, and so we explore every time all the strip surface.

All trees and lianas with DBH $\geq 10 \mathrm{~cm}$ were shortlisted and DBH (Diameter at Breast Height, measured at $1.3 \mathrm{~m}$ from the ground level) and height (m) were measured. The plant specimens were collected and determined by comparison with plant herbariums of the Department of Plant Biology of the Higher Teacher Training College and the National Herbarium of Cameroon (YA) in Yaoundé, while using the volumes of the flora of Cameroon (Aubréville et al., 1963-1998), Flora of West Tropical Africa, FWTA (Hutchinson and Dalziel, 1954-1972), and some books (Normand, 1965; Vivien and Faure, 1985). All woody plants $\geq 10 \mathrm{~cm} \mathrm{DBH}$ were identified to species Data from all the plots were pooled for analysis.

On the basis of these data, we represented the curves of species-strength accumulation of different categories of DBH and species-area accumulation (Gounot, 1969) and various values were calculated: basal area or surface of the species on the soil, the index value of importance of the families (Family Importance Value, FIV; Mori et al., 1983) and the index value of importance of the species (Importance Index Value, IVI; Cottam and Curtis, 1956). The diversity was evaluated by the following index:

-index of diversity of Shannon and Weaver (1949): ISH $=-\sum \mathrm{Ni} / \mathrm{N} \log _{2} \mathrm{Ni} / \mathrm{N}$;

- index of heterogeneity of Simpson (Colinvaux, 1986): D'= (Ni/N) ${ }^{2}$;

- equitability of Pielou (1966): EQ = ISH/ $\log _{2} \mathrm{~S}$;

Where $\mathrm{S}$ is the number of species of the dition; $\mathrm{Ni}$ is the number of the species $\mathrm{i}$ and $\mathrm{N}$ the strength of all species. It is expressed in bits;

\section{Results}

\subsection{Forest Structure}

In one hectare sampled, a density of 763 trees $\mathrm{DBH} \geq 10 \mathrm{~cm}$ was recorded, representing a basal 


\section{Macrothink}

area of $61.69 \mathrm{~m}^{2}$. The floristic list is made up of 40 species all identified (Appendix 1). They are distributed in 35 genus and 20 families. The richest families were the Euphorbiaceae and the Rubiaceae represented each by 6 species. These taxa drift of 763 recorded trees on 1-ha plot.

Considering tree diameter, $70.77 \%$ of individuals occurring within the $10-30 \mathrm{DBH}$ size-class, $25.95 \%$ in the $30-70 \mathrm{~cm}$ range. The lower percentage occured in the $70-120 \mathrm{~cm}$ range (3.27\%). Only $0.26 \%$ of trees occured in the maximum DBH size-class $(110-120 \mathrm{~cm})$. Altogether, $86.1 \%$ of trees are less than $40 \mathrm{~cm} \mathrm{DBH} \mathrm{(Appendix} \mathrm{1).} \mathrm{The} \mathrm{biggest} \mathrm{trees}$ represented by Schefflera barteri, Polyscias fulva and Carapa grandiflora had a DBH of 108,113 and $117 \mathrm{~cm}$ respectively. Twenty-five trees belonging to 6 species had a DBH $\geq 70 \mathrm{~cm}$. The distribution in DBH classes shows an inverse-shaped curve (Figure 2).

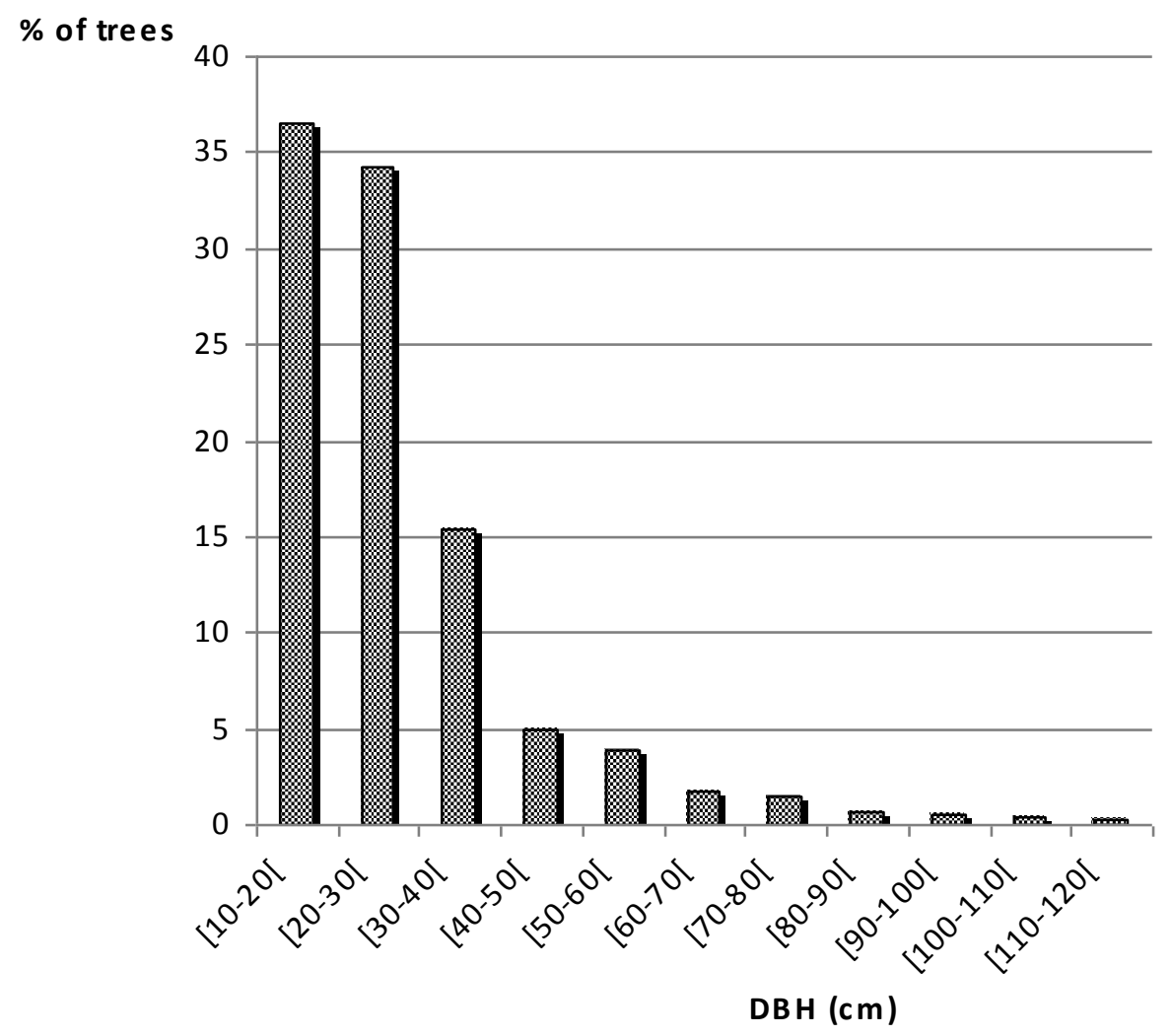

Figure 2. Size classes of all 763 trees $(\geq 10 \mathrm{~cm} \mathrm{dbh})$, from 40 species.

When one considers the diversities of the 3 strata, the number of recorded species and the different indexes are presented in the Table 1. The lower stratum is always the more diversified.

Table 1. Diversity of 3 strata (RS: specific richness, N: number of ligneous species whose distribution is observed, ISH: Shannon specific diversity index values and EQ: Pielou equitability index values.

\begin{tabular}{|l|l|l|l|l|l|}
\hline Plant strata & diameter classes & RS & N & ISH & EQ \\
\hline Highest stratum & DBH $\geq 70 \mathrm{~cm}$, & 25 & 6 & 2.2 & 0.85 \\
\hline Middle stratum & $30 \leq \mathrm{DBH}<70$ & 198 & 21 & 3.47 & 0.99 \\
\hline Lower stratum & $10 \leq \mathrm{DBH}<30 \mathrm{~cm}$ & 530 & 40 & 3.81 & 0.72 \\
\hline
\end{tabular}




\section{Macrothink}

The number of species inventoried by plot of 0.1 ha varies from 8 to 17 with an average of 12.6 species per plot. The species-area accumulation curve for the whole survey is drawn (Figure 6).

On the same level of sampling effort, for 25 individuals observed in each stratum, the results are presented in Table 2. The lower stratum (ligneous with $10 \leq \mathrm{DBH}<30 \mathrm{~cm}$ ) is the more diversified with 18 plant species. The species-sampling size accumulation curves are drawn for 3 diameter intervals (Figure 3). The lower stratum shows a fast increasing number of species and describes a landing subparallel to the axis of the abscissas. The woody plants with $10 \leq \mathrm{DBH}<30 \mathrm{~cm}$ present faster growth and also describe a landing. The curve of the emergent stratum stays in the fringe that didn't yet reach the landing.

Table 2. Sampling size and diversity of 25 ligneous by stratum (RS: specific richness, N: number of ligneous species whose distribution is observed, ISH: Shannon specific diversity index values and EQ: Pielou equitability index values).

\begin{tabular}{|l|l|c|c|c|c|}
\hline Plant strata & diameter classes & RS & N & ISH & EQ \\
\hline Highest stratum & DBH $\geq 70 \mathrm{~cm}$ & 25 & 6 & 2.2 & 0.85 \\
\hline Middle stratum & $30 \leq \mathrm{DBH}<70$ & 25 & 12 & 3.43 & 0.96 \\
\hline Lower stratum & $10 \leq \mathrm{DBH}<30 \mathrm{~cm}$ & 25 & 18 & 4.42 & 0.96 \\
\hline
\end{tabular}

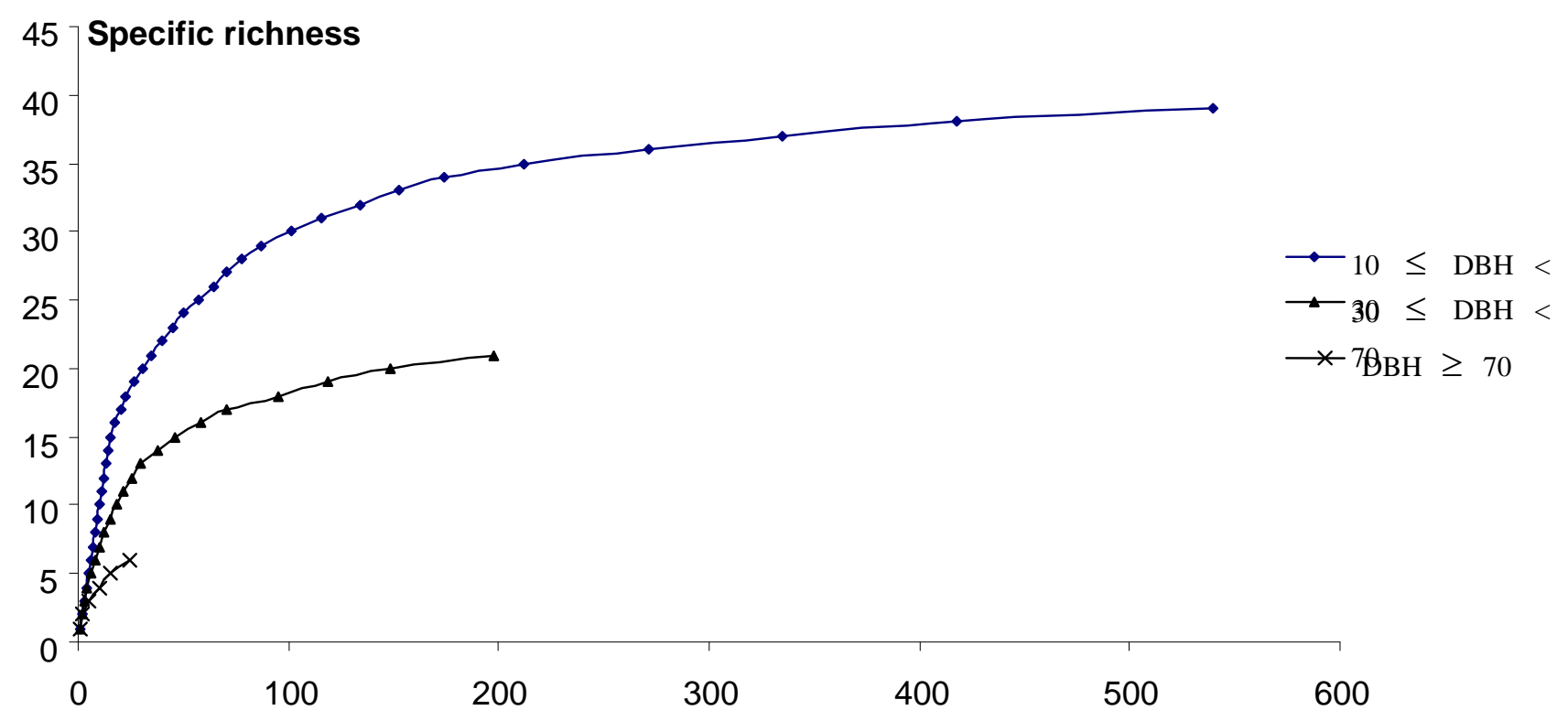

\section{Number of trees}

Figure 3. Species strength accumulation curve of 3 categories of DBH (DBH $\geq 70,30$ and 10 $\mathrm{cm}$ ) on the entirety of the inventory, with respect to each of these categories.

\subsection{Phytogeographic and Phytosociologic Affinities}

We identified all the 40 species recorded on the plot to the specific level, but the introduced Persea americana is not taken into account. The known distribution of the species is given in 
Appendix 1 and reveals that 2 species (Allophylus bullatus and Schefflera mannii) are endemic to the Cameroonian high mountains archipelago (Letouzey, 1985). Within the tropical region, the occurrence of these species is given (Table 3). The contribution of Manengouba local endemic is 5\%. The majority of the species (15 species; 41\%) are highlander and $23 \%$ submountain. Regarding phytosociologic aspect, the different taxa are in Table 3. Only the intermediate combination between two successive types of the pressure gradient (and no disconnected) are generally feasible for species of liaison (Senterre, 2005). The majority of the species (85\%) belong to the rainforests (Strombosio-Parinarietea). The other species are features of the secondary mountain forests (Polyscietalia fulvae) $(7.5 \%)$ and of secondary planitiary forests (Musango-Terminalietea) $(5.65 \%)$.

Table 3. Phytogeographic and phytosociologic affinities of the identified species of the Manengouba sampling.

\begin{tabular}{|c|c|c|c|c|c|}
\hline Altitudinal strata & \multicolumn{2}{|l|}{ Lowlands stratum } & $\begin{array}{l}\text { Submountain } \\
\text { stratum }\end{array}$ & \multicolumn{2}{|c|}{ lower mountain stratum (high hygrometry) } \\
\hline \multirow{2}{*}{$\begin{array}{l}\text { Phytogeographic } \\
\text { affinities }\end{array}$} & \multicolumn{2}{|c|}{$\mathrm{Bm}, \mathrm{Bm}+\mathrm{Sm}$} & $\mathrm{Sm}, \mathrm{Sm}+$ & \multicolumn{2}{|l|}{$\mathrm{Mi}, \mathrm{Mi}+\mathrm{Ms}$} \\
\hline & & \multicolumn{3}{|c|}{ Strombosio-Parinarietea Lebrun \& Gilbert 1954} & \\
\hline $\begin{array}{l}\text { Phytosociologic } \\
\text { groups }\end{array}$ & $\begin{array}{l}\text { Musango-Terminalietea } \\
\text { Lebrun and Gilbert } \\
1954\end{array}$ & $\begin{array}{l}\text { Gilbertiodendretalia } \\
\text { dewevrei Lebrun } \\
\text { and Gilbert } 1954\end{array}$ & $\begin{array}{l}\text { Garcinietalia } \\
\text { Noumi } 1998\end{array}$ & $\begin{array}{l}\text { Ficalhoeto-Podocarpetalia } \\
\text { Lebrun and Gilbert } 1954\end{array}$ & $\begin{array}{l}\text { Polyscietalia } \\
\text { fulvae } \\
\text { Lebrun and } \\
\text { Gilbert } 1954\end{array}$ \\
\hline $\begin{array}{l}\text { Number of } \\
\text { species }\end{array}$ & 5 & 12 & 7 & 10 & 5 \\
\hline
\end{tabular}

$\mathrm{Bm}$ (lower and middle altitudes), $\mathrm{Bm}+\mathrm{Sm}$ (low and medium altitudes going up to $\mathrm{Sm}$ ), Sm (Submountain altitude), Sm + Mi (Submountain going up in Mi), Mi (lower highlander, (strong hygrometry), Mi + Ms (lower highlander going up in Ms), Ms (superior highlander, weak) hygrometry).

\subsection{Floristic Composition}

Family level - Three families Fabaceae, Mimosaceae and Caesalpiniaceae are treating as a single family (Leguminosae). So, we recorded twenty families in the sampling. The ten most important families for each relative parameter and FIV are listed in Table 4. The value of each relative parameter for the ten families with highest FIV is represented in Figure 4. The complete results for each family are given in Appendix 2.

Table 4. Families with highest values of relative diversity, relative density, relative dominance and FIV in decreasing order. Families that do not rank among the ten most important in FIV value appear in bold type.

\begin{tabular}{|c|c|c|c|}
\hline $\begin{array}{l}\text { Relative diversity } \quad[\mathrm{x} \\
100 \%]\end{array}$ & $\begin{array}{l}\text { Relative density } \\
\text { [x 100\%] }\end{array}$ & $\begin{array}{l}\text { Relative dominance } \quad[\mathrm{x} \\
100 \%]\end{array}$ & $\begin{array}{l}\text { FIV } \\
300 \%]\end{array}$ \\
\hline
\end{tabular}




\begin{tabular}{|l|r|l|r|l|r|l|r|}
\hline Euphorbiaceae & 15 & Myrsinaceae & 28.44 & Araliaceae & 29.11 & Rubiaceae & 56.19 \\
\hline Rubiaceae & 15 & Rubiaceae & 25.69 & Euphorbiaceae & 25.77 & Euphorbiaceae & 55.71 \\
\hline Araliaceae & 10 & Euphorbiaceae & 14.94 & Myrsinaceae & 16.08 & Araliaceae & 51.03 \\
\hline Moraceae & 7.5 & Araliaceae & 11.93 & Rubiaceae & 15.50 & Myrsinaceae & 49.52 \\
\hline Myrsinaceae & 5 & Meliaceae & 5.24 & Meliaceae & 5.81 & Meliaceae & 16.06 \\
\hline Meliaceae & 5 & Cyatheaceae & 1.97 & Opiliaceae & 1.67 & Moraceae & 8.33 \\
\hline Rutaceae & 5 & Opiliaceae & 2.49 & Rutaceae & 1.51 & Rutaceae & 7.95 \\
\hline Cyatheaceae & 5 & Thymelaeaceae & 2.49 & Rosaceae & 1.33 & Cyatheaceae & 7.40 \\
\hline Sapindaceae & 5 & Rutaceae & 1.44 & Melianthaceae & 0.71 & Opiliaceae & 6.66 \\
\hline Opiliaceae & 2.5 & Rosaceae & 1.31 & Thymelaeaceae & 0.60 & Sapindaceae & 6.19 \\
\hline & & & & & & & \\
\hline
\end{tabular}

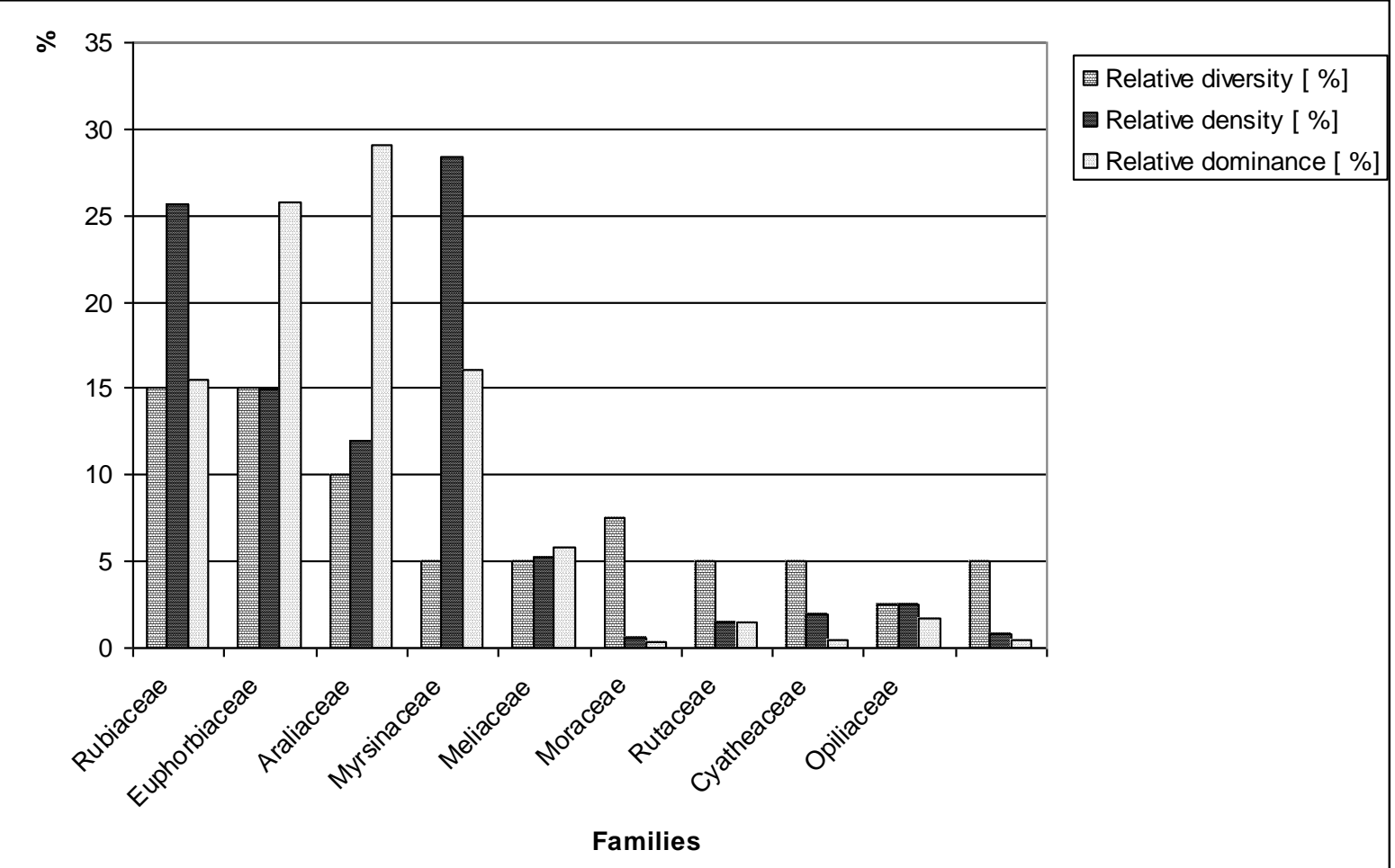

Figure 4. Relative diversity, Relative density and relative dominance of the ten most important families in FIV.

Regarding relative density, the ten most abundant families are Myrsinaceae, Rubiaceae,Euphorbiaceae, Araliaceae, Meliaceae, Opiliaceae, Thymelaeaceae, Cyatheaceae, Rutaceae and Rosaceae. The density of each other family does not reach 6\%. Myrsinaceae, Rubiaceae, Euphorbiaceae and Araliaceae are clearly the most abundant families. Together they contribute $81 \%$ of all trees in the sampling inventory (Table 4 ).

Families with highest dominance are Araliaceae, Euphorbiaceae, Myrsinaceae, Rubiaceae, Meliaceae, Opiliaceae, Rutaceae, Rosaceae,,Melianthaceae and Thymeliaceae. Araliaceae, Euphorbiaceae, Myrsinaceae and Rubiaceae together account for $86.49 \%$ of the total basal area. The ten most species-rich families are Rubiaceae, Euphorbiaceae, Araliaceae, Moraceae, 
Myrsinaceae, Rutaceae, Cyatheaceae, Sapindaceae, Meliaceae and Opiliaceae. The relative diversity of Rubiaceae (6 species) represents $15 \%$ of the total species diversity of the sampling. Eleven families are represented by a single species, 5 by 2 species, 1 by 3 species and 1 by 4 species (Appendix 2).

With regard to Family Importance Value (FIV), Rubiaceae (italic) are the most important family in the sampling with a FIV of 56.19. They also have the highest relative diversity (with Euphorbiaceae) and the higher relative density values. When comparing FIV and the 3 relative values of the ten most important families, only Rubiaceae, Euphorbiaceae, Araliaceae, Myrsinaceae, Meliaceae, Rutaceae Cyatheaceae and Opiliaceae appeared among the first ten families for all parameters. Sapindaceae are tenth in FIV due to their relative diversity. Moraceae are 4th in relative diversity but they drop to the position $6^{\text {th }}$ in FIV because of their low relative density and dominance. Considering relative dominance, three familes: Rosaceae, Melianthaceae and Thymeliaceae have some appreciated values and account for $2.64 \%$ of the total basal area, but are represented by only one species and a few individuals respectively. Thus the two families are not among the ten families with the highest FIV.

Specific level - We recorded forty species in the sampling. The authors of scientific name appear in appendix 1. Table 5 lists the ten most important species in each relative parameter. The values of each parameter for the ten species with the higher IVI are represented in Figure 5. Appendix 3 gives the results for all species. A small group of species dominates the plot: 5 species (12.5\% of the total number of species) account for $63.96 \%$ of all trees. The majority of species (47.5) are represented by lest than 5 individuals: 2 species are represented by 2 individuals, but 13 species (32.5\%) are represented by a single individual. Regarding relative dominance, less than $10 \%$ of the species contribute $54.78 \%$ of total basal area. High dominance can be achieved by a great number of small trees or by a few large trees. Schefflera abyssinica is $9^{\text {th }}$ in relative density ( 22 individuals) but drops to $20^{\text {th }}$ position in relative dominance. Opilia celtidifolia is $4^{\text {th }}$ in relative frequency, but it is $11^{\text {th }}$ in both relative density and relative dominance.

Table 5. Species with highest values of relative frequency, relative density, relative dominance and IVI in decreasing order. Species that do not rank among the ten most important in IV I value appear in bold characters.

\begin{tabular}{|l|c|l|l|l|l|l|l|}
\hline \multicolumn{2}{|l|}{$\begin{array}{l}\text { Relative frequency } \\
\text { [x 100\%] }\end{array}$} & \multicolumn{2}{|l|}{$\begin{array}{l}\text { Relative density } \\
{[\mathrm{x} 100 \%]}\end{array}$} & \multicolumn{2}{|l|}{$\begin{array}{l}\text { Relative dominance } \\
100 \%]\end{array}$} & $\begin{array}{l}\text { IV I } \\
300 \%]\end{array}$ \\
\hline $\begin{array}{l}\text { Rapanea } \\
\text { melanophloeos }\end{array}$ & 7.52 & $\begin{array}{l}\text { Rapanea } \\
\text { melanophloeos }\end{array}$ & 16.25 & $\begin{array}{l}\text { Macaranga } \\
\text { occidentalis }\end{array}$ & 20.65 & $\begin{array}{l}\text { Macaranga } \\
\text { occidentalis }\end{array}$ & 37.35 \\
\hline Polyscias fulva & 7.52 & $\begin{array}{l}\text { psydrax } \\
\text { arnoldianum }\end{array}$ & 12.45 & Polyscias fulva & 13.36 & $\begin{array}{l}\text { Rapanea } \\
\text { melanophloeos }\end{array}$ & 30.48 \\
\hline Schefflera mannii & 6.02 & Maesa lanceolata & 12.19 & Schefflera barteri & 11.39 & Maesa lanceolata & 26.08 \\
\hline Opilia celtidifolia & 5.26 & $\begin{array}{l}\text { Macaranga } \\
\text { occidentalis }\end{array}$ & 12.19 & Maesa lanceolata & & Polyscias fulva & 24.16 \\
\hline $\begin{array}{l}\text { psydrax } \\
\text { arnoldianum }\end{array}$ & 4.51 & $\begin{array}{l}\text { Rothmannia } \\
\text { urcelliformis }\end{array}$ & 10.88 & $\begin{array}{l}\text { Rothmannia } \\
\text { urcelliformis }\end{array}$ & 7.66 & $\begin{array}{l}\text { psydrax } \\
\text { arnoldianum }\end{array}$ & 23.44 \\
\hline
\end{tabular}




\begin{tabular}{|c|c|c|c|c|c|c|c|}
\hline Maesa lanceolata & 4.51 & Schefflera barteri & 4.46 & $\begin{array}{l}\text { Rapanea } \\
\text { melanophloeos }\end{array}$ & 6.71 & $\begin{array}{l}\text { Rothmannia } \\
\text { urcelliformis }\end{array}$ & 22.30 \\
\hline $\begin{array}{l}\text { Macaranga } \\
\text { occidentalis }\end{array}$ & 4.51 & $\begin{array}{l}\text { Carapa } \\
\text { grandiflora }\end{array}$ & 3.54 & $\begin{array}{l}\text { psydrax } \\
\text { arnoldianum }\end{array}$ & 6.48 & Schefflera barteri & 18.85 \\
\hline $\begin{array}{l}\text { Croton } \\
\text { macrostachyus }\end{array}$ & 4.51 & Polyscias fulva & 3.28 & $\begin{array}{l}\text { Carapa } \\
\text { grandiflora }\end{array}$ & 4.34 & $\begin{array}{l}\text { Carapa } \\
\text { grandiflora }\end{array}$ & 11.64 \\
\hline $\begin{array}{l}\text { Rothmannia } \\
\text { urcelliformis }\end{array}$ & 3.76 & $\begin{array}{l}\text { Schefflera } \\
\text { abyssinica }\end{array}$ & 2.88 & $\begin{array}{l}\text { Croton } \\
\text { macrostachyus }\end{array}$ & 3.34 & Schefflera mannii & 10.57 \\
\hline Prunus africana & 3.76 & Opilia celtidifolia & 2.49 & Schefflera mannii & 3.24 & $\begin{array}{l}\text { Croton } \\
\text { macrostachyus }\end{array}$ & 9.81 \\
\hline
\end{tabular}

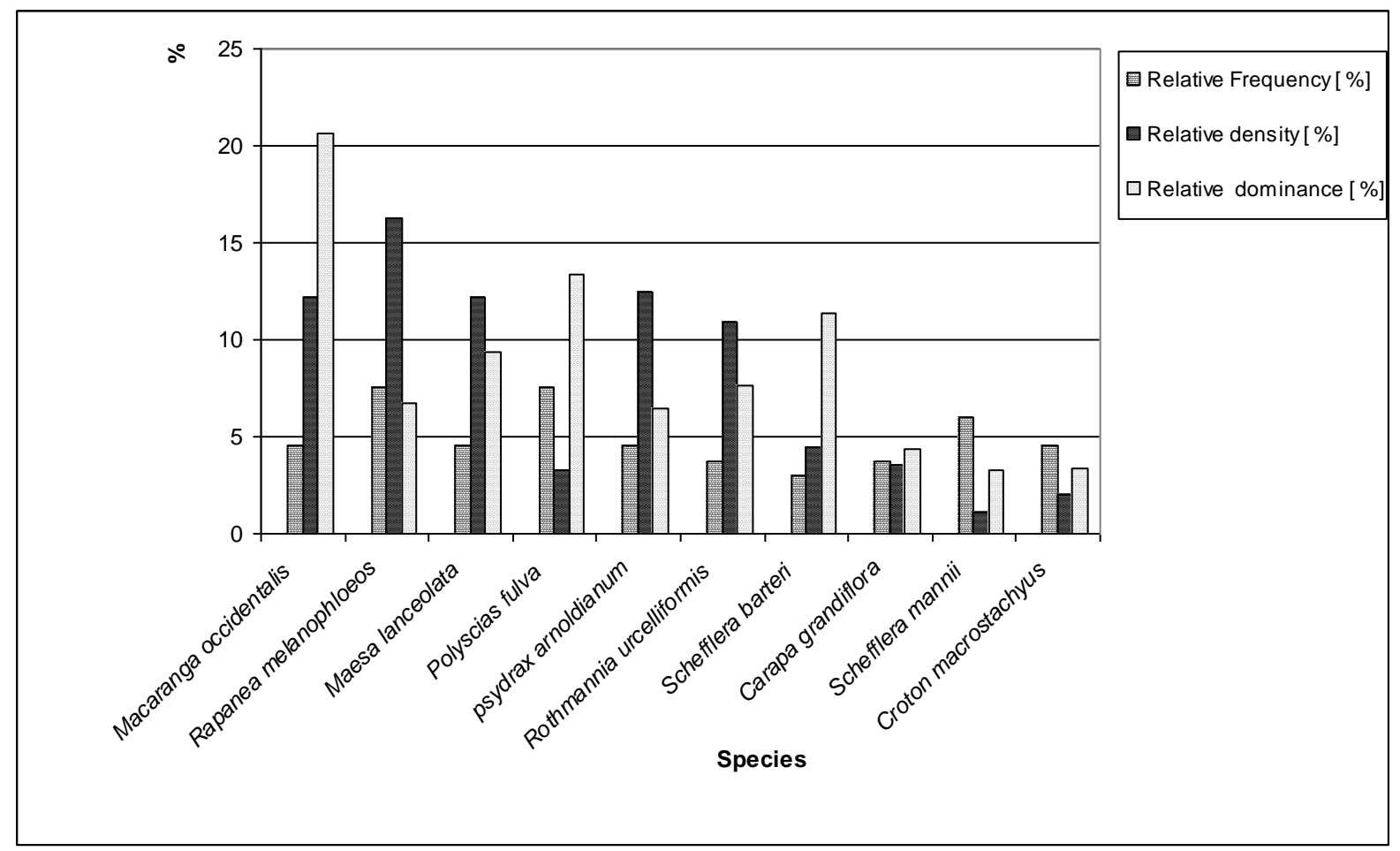

Figure 5. Relative frequency, relative density, and relative dominance of the ten most important species in IVI.

\section{Discussion}

The comparisons between the data of this survey and those of other dense forests of Africa, Madagascar and Neotropic region are based on the floristic and structural, quantitative and qualitative parameters. The main aim was to determine the parameters that make the differences and those that bring them closer, to highlight the features closed to the Manengouba highlander forest.

\subsection{Manengouba Forest Structure}

The species-area accumulation curve for the plot is drawn and compared to those of some samplings of central Africa (Figure 6). In any case, the expression of the study area shows quantitatively low data. It follows a classical accumulation curve. In any consecutive quadrat, new species were encountered making it difficult to determine if one ha is satisfactory for a 
fully representative sample for the forest. In fact it is observable in the accumulation curve. Nevertheless in the other central African forests, new species always occur in spite the altitude and of the inventoried surface. One can presume that 1-ha surface is suitable for the study (D'Amico and Gautier, 2000; Nusbaumer et al., 2005).

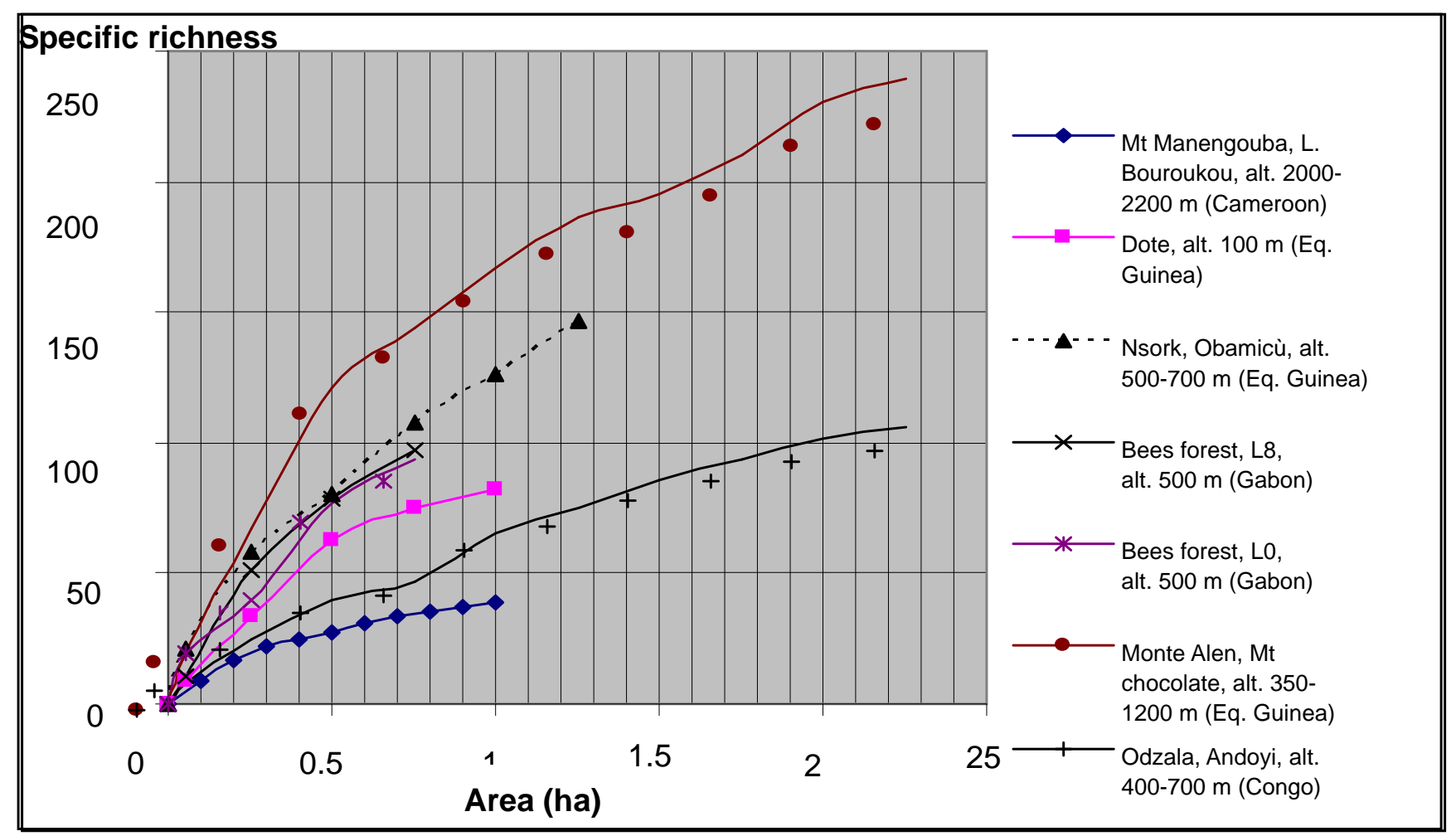

Figure 6. Species-area accumulation curve of the 1-ha plot in the Manengouba highlander forest (each sub-unit is represented by $40 \times 25 \mathrm{~m}=0.1$ ha) and 6 species-area accumulation curves achieved in Atlantic central Africa; Dote (Collin, 1998), Bees forest, L.0 et L.8 (Gesnot, 1994), Monte Alèn (Van Reeth, 1997), Nsork (Senterre, 2005), Odzala, (Van Asbroeck, 1997).

The density of 763 trees $\geq 10 \mathrm{~cm} \mathrm{DBH}$ is within the range of 167 to 1947 individuals per hectare reported by (Gentry, 1982) for Neotropical forests sampled by different methods, and the range of 542 to 1223 trees/ha $(\mathrm{DBH} \geq 10 \mathrm{~cm}$ ) (Rabevohitra et al., 1996; Rakotomalaza \& Messmer, 1999) recorded in a series of 1-ha plots set low elevation rainforests in the eastern Madagascar. The comparison with inventoried trees of tropical rainforests sampled in various continents shows that tree density seems to have a high similar range of variation in the mountain forests throughout the world (Mohandass and Davidar, 2009) but, no matter the altitude (Table 6).

Table 6. Number of trees per hectare $(\mathrm{dbh} \geq 10 \mathrm{~cm})$ in Manengouba rainforest and in lowland rainforests sites in Africa, Madagascar and Neotropic regions, by decreasing density.

\begin{tabular}{|l|l|l|l|}
\hline Sites & Countries & References & $\begin{array}{l}\text { Number of } \\
\text { trees/ha }\end{array}$ \\
\hline Andranomintina (plot 1), & Madagascar & Rabevohitra et al., 1996 & 1223 \\
\hline
\end{tabular}




\begin{tabular}{|c|c|c|c|}
\hline Shola montane evergreen forest & Nilgiri, India & $\begin{array}{ll}\text { Mohandass } & \text { and } \\
\text { Davidar, } 2009 & \end{array}$ & 832 \\
\hline Manengouba forest (Mbouroukou) & Cameroon & Present study & 763 \\
\hline Yasuni (unflooded forest), & Ecuator & Balslev et al., 1987 & 728 \\
\hline Lowland rainforest in Manongarivo & Madagascar & $\begin{array}{l}\text { D'Amico and Gauthier, } \\
2000\end{array}$ & 728 \\
\hline Yapo (unfloodplain forest), & Côte d'Ivoire & Corthay, 1996 & 649 \\
\hline Alto Ivon, & Bolivia & Boom, 1986 & 649 \\
\hline Forest of Ngotto & $\begin{array}{l}\text { Centrafrican } \\
\text { Republic }\end{array}$ & Lejoly, 1995 & 549 \\
\hline Forestry Reserve of Dja (Alat 1.7) & Cameroon & Sonké, 1998 & 513 \\
\hline $\begin{array}{l}\text { Forest with Cleistopholis patens and } \\
\text { Ficus mисиso }\end{array}$ & Benin & Sokpon, 1995 & 494 \\
\hline Oveng & Gabon & Reitsma, 1988 & 485 \\
\hline Jenaro Herrera & Peru & Spichiger et al., 1996 & 482 \\
\hline Bees forest & Gabon & Gesnot, 1994 & 458 \\
\hline Yasuni (floodplain forest), & Ecuator & Balslev et al., 1987 & 417 \\
\hline Classified forest of Scio & Côte d'Ivoire & Nusbaumer et al., 2005 & 413 \\
\hline Lopé (site 1) & Gabon & White, 1992 & 304 \\
\hline National Park of Odzala (layon Andzoyi) & Congo & Lejoly, 1996 & 294.7 \\
\hline
\end{tabular}

The structure the Menengouba mountain forest is in a high range as the montane Shola forests of the Nilgiris (Mohandass and Davidar, 2009). The basal area $\left(61.69 \mathrm{~m}^{2} / \mathrm{ha}\right)$ is more elevated than the value reported by D'Amico \& Gauthier (2000) and those reported by Mori et al. (1983) for five moist lowland neotropical forests (ranging from $21.5-53.0 \mathrm{~m}^{2} / \mathrm{ha}$ ) sampled by the point centered quarter method (Cottam \& Curtis, 1956). Basal areas have also been found in other lowland rainforests of Madagascar sampled using the permanent 1-ha plot method: $34.1 \mathrm{~m}^{2} / \mathrm{ha}$ at Andohahela (Rakotomalaza \& Messmer, 1999), and a range of 19.0 to $38.9 \mathrm{~m}^{2} / \mathrm{ha}$ in ten different eastern lowland forests (Rabevohitra et al., 1996), or in African lowland rainforest of : $19.2 \mathrm{~m}^{2} /$ ha in Cameroon (Lejoly, 1996) ; $42.32 \mathrm{~m}^{2} / \mathrm{ha}$ in Benin (Sokpon, 1995) ; $30.82 \mathrm{~m} / \mathrm{ha}$ in Côte-d'Ivoire (Nusbaumer et al., 2005). Many works over the world show lower values of basal area than Manengouba highland forest (Table 7). In this study the value of the basal area and the distribution of the diameter classes observed are typical of a forest in good state of conservation (Rollet, 1979). The forest remains always in the state of growth, due to its mesologic characters (Lebrun and Gilbert, 1954). The individuals of the mountain ombrophile species (Carapa grandiflora, Macaranga occidentalis, Polyscias fulva, Schefflera barteri and Schefflera mannii) gain dimension.

Table 7. Basal area/ha in the Manengouba forest and lowland rainforests altitudes, in Africa and other areas, in deceasing dominance.

\begin{tabular}{|l|l|l|l|}
\hline Sites & Countries & References & $\begin{array}{l}\text { basal area } \\
\left(\mathrm{m}^{2}\right)\end{array}$ \\
\hline Manengouba forest (Mbouroukou) & Cameroon & Present study & 61.69 \\
\hline
\end{tabular}




\begin{tabular}{|l|l|l|c|}
\hline Shola montane evergreen forest & Nilgiri, India & $\begin{array}{l}\text { Mohandass and Davidar, } \\
2009\end{array}$ & 53.55 \\
\hline $\begin{array}{l}\text { Cleistopholis patens and Ficus mucuso } \\
\text { forest }\end{array}$ & Benin & Sokpon, 1995 & 42.3 \\
\hline Yapo classified forest & Côte-d'Ivoire & Corthay, 1996 & 40.0 \\
\hline Dja Forestry Reserve (Alat 1.7) & Cameroon & Sonké, 1998 & 34.2 \\
\hline Yasuni (unflooded forest) & Ecuator & Balslev et al., 1987 & 33.7 \\
\hline Scio Classified forest & Côte d'Ivoire & Nusbaumer et al., 2005 & 30.82 \\
\hline Andranomintina (plot 1) & Madagascar & Rabevohitra et al., 1996 & 27.9 \\
\hline Andranomintina (plot 2) & Madagascar & Rabevohitra et al., 1996 & 25.3 \\
\hline Jenaro Herrera & Peru & Spichiger et al., 1996 & 22.6 \\
\hline Manongarivo & Madagascar & D'Amico and Gauttier,2000 & 22.4 \\
\hline
\end{tabular}

\subsection{Floristic Composition}

The floristic list is composed of 40 species all identified (Appendix 1) from which are derivates 35 genus and 20 families. The nomenclature follows Lebrun \& Stork (1991-1997).

Family level - In the plot sampled, more than $58 \%$ of all trees are represented by 3 families. According to Rabevohitra et al. (1996) 4, 5 or 6 families always represent more than $50 \%$ of total trees in littoral forests along Madagascar's east coast. Table 8 shows that in Manengouba forest and 3 sub mountain forests inventories in Cameroon, Apocynaceae, Euphorbiaceae, Leguminosae (capital), Meliaceae and Rubiaceae are frequently among the ten most abundant families. Araliaceae is the mountain forest family.

Table 8. The ten most abundant families in Manengouba forest and three Cameroonian submountain forests (available data). Families among the ten most abundant in at least 3 plots appear in bold letters.

\begin{tabular}{|l|l|l|l|}
\hline Messa forest & Kala forest & Kouoghap Sacral forest (SF) & Manengouba forest \\
\hline Tagne, 2007 & Madiapevo, 2008 & Noumi (2012) & Present study \\
\hline Alt. 900-1015 m & Alt. 1000-1156 m & Alt. 1400-1550 m & $2200-2396 \mathrm{~m}$ \\
\hline Sterculiaceae & Myristicaceae & Rubiaceae & Rubiaceae \\
\hline Moraceae & Clusiaceae & Meliaceae & Euphorbiaceae \\
\hline Euphorbiaceae & Leguminosae & Moraceae & Araliaceae \\
\hline Leguminasae & Annonaceae & Bignoniaceae & Moraceae \\
\hline Meliaceae & Rubiaceae & Apocynaceae & Myrsinaceae \\
\hline Apocynaceae & Sterculiaceae & Sapotaceae & Meliaceae \\
\hline Caricaceae & Meliaceae & Leguminosae & Rutaceae \\
\hline Myristicaceae & Apocynaceae & Euphorbiaceae & Cyatheaceae \\
\hline Lauraceae & Burseraceae & Araliaceae & Sapindaceae \\
\hline Ulmaceae & Euphorbiaceae & Clusiaceae & Opiliaceae \\
\hline
\end{tabular}

Family composition of Lowlads forests of the tropics tend to be similar (Gentry, 1988). This latter listed 11 families (Leguminosae, Lauraceae, Annonaceae, Rubiaceae, Moraceae, 


\section{Mll Macrothink}

Journal of Biology and Life Science ISSN 2157-6076 2013, Vol. 4, No. 2

Myristicaceae, Sapotaceae, Meliaceae, Arecaceae, Euphorbiaceae and Bignoniaceae) that contribute half of the species' richness to 1-ha samplings in lowland neotropical forests. At least eight of these families are always among the ten richest species in Africa and Asia as well. This is not the case with the Manengouba highlander forest. Only 5 families (Rubiaceae Euphorbiaceae Araliaceae Moraceae Myrsinaceae) contribute half of the species' richness to 1-ha plot in the Manengouba forest. The same families, except for Moraceae, are the richest species. Five families (Myrsinaceae, Rubiaceae, Euphorbiaceae, Araliaceae, Meliaceae) are among the ten most important families for relative density and FIV in the plot sampled here (Table 9). The dominance of Leguminosae in the neotropic regions and Africa is equal when only the trees in DBH $\geq 10 \mathrm{~cm}$ are considered (Gentry, 1988). The Leguminosae is among the first families in FIV in the lowland and submountain forests (Table 9). It no longer has a representative in the highlander Manengouba forest. The same is observed in an inventory of all plants $\geq 1 \mathrm{~cm}$ dbh recorded in 19 sholas of total area 11.5 ha (Mohandass and Davidar, 2009).

It is remarkable that in the Cameroonian highland forests, Rubiaceae seem to be more important than in Neotropical (capital) and African lowland forests. At Manengouba it is the first in FIV accumulation values (FIV: 56.19), while it is $4^{\text {th }}$ with an FIV of 21.23 at Manongarivo (D'Amico and Gautier, 2000), $6^{\text {th }}$ with an FIV value of 14.71 at Yasuni (Balslev et al., 1987), 10 ${ }^{\text {th }}$ with an FIV value of 8.3 at Alto Ivon (Boom, 1986), 14 ${ }^{\text {th }}$ with an FIV value of 7.79 at Jenera Herrera (Spichiger et al., 1996). The scarcity of Rubiaceae is observed as recorded in many lowland forests (Table 9). On the one hand in Cameroon, Rubiaceae are much more abundant and more species-rich in the highland forests (Tagne, 2007; Madiapevo, 2008; Noumi, 2012), on the other hand at Manengouba Myrsinaceae are the much more abundant, the Rubiaceae and Euphorbiaceae are the most diversified.

Table 9. Family Importance Value of the 15 most important plant families in Manengouba and 3 other Cameroonian highland forests, and 7 lowland tropical forests reported by D'Amico and Gautier (2000) (for Mori et al. 1983, only the first 10 were reported).

\begin{tabular}{|l|l|l|l|l|l|l|r|}
\hline \multicolumn{2}{|l}{$\begin{array}{l}\text { SF Kouoghap (Cameroon) } \\
\text { Noumi } \\
2012\end{array}$} & $\begin{array}{l}\text { Kala forest (Cameroon) } \\
\text { Madiapevo, 2008 }\end{array}$ & $\begin{array}{l}\text { Messa forest } \\
\text { Cameroon) } \\
\text { Tagne, 2007 }\end{array}$ & & \multicolumn{3}{l|}{$\begin{array}{l}\text { Manengouba forest } \\
\text { (ameroon) } \\
\text { Present study }\end{array}$} \\
\hline Families & FIV & Families & FIV & Families & FIV & Families & FIV \\
\hline Meliaceae & 33.38 & Leguminosae & 31.00 & Leguminosae & 47.60 & Rubiaceae & 56.19 \\
\hline Leguminosae & 32.63 & Clusiaceae & 27.90 & Sterculiaceae & 33.17 & Euphorbiaceae & 55.71 \\
\hline Moraceae & 31.81 & Myristicaceae & 26.80 & Moraceae & 28.93 & Araliaceae & 51.03 \\
\hline Sapotaceae & 26.83 & Burseraceae & 21.77 & Euphorbiaceae & 26.11 & Myrsinaceae & 49.52 \\
\hline Rubiaceae & 26.12 & Sterculiaceae & 21.41 & Meliaceae & 17.26 & Meliaceae & 16.06 \\
\hline Bignoniaceae & 21.16 & Annonaceae & 18.24 & Apocynaceae & 13.90 & Moraceae & 8.33 \\
\hline Apocynaceae & 19.49 & Rubiaceae & 17.96 & Myristicaceae & 12.59 & Rutaceae & 7.95 \\
\hline Euphorbiaceae & 15.74 & Meliaceae & 17.83 & Ulmaceae & 12.26 & Cyatheaceae & 7.40 \\
\hline Verbenaceae & 12.51 & Euphorbiaceae & 15.78 & Caricaceae & 10.57 & Opiliaceae & 6.66 \\
\hline Annonaceae & 11.23 & Apocynaceae & 13.76 & Rubiaceae & 10.12 & Sapindaceae & 6.19 \\
\hline
\end{tabular}




\section{Macrothink}

Journal of Biology and Life Science

ISSN 2157-6076

2013, Vol. 4, No. 2

\begin{tabular}{|c|c|c|c|c|c|c|c|}
\hline Burseraceae & 9.65 & Irvingiaceae & 8.18 & Bombacaceae & 7.44 & Thymelaeaceae & 5.59 \\
\hline Sterculiaceae & 9.33 & Moraceae & 8.13 & Cecropiaceae & 7.38 & Rosaceae & 5.14 \\
\hline Araliaceae & 7.70 & Cecropiaceae & 7.92 & Combretaceae & 7.37 & Melianthaceae & 4.26 \\
\hline Agavaceae & 6.83 & Flacourtiaceae & 7.43 & Lauraceae & 7.19 & Asteraceae & 3.14 \\
\hline Clusiaceae & 6.66 & Sapotaceae & 7.38 & Olacaceae & 6.85 & Alangiaceae & 3.10 \\
\hline \multicolumn{2}{|l|}{ Yapo (Ivory Coast ) } & \multicolumn{2}{|c|}{$\begin{array}{l}\text { Manongarivo(Madagascar) } \\
\text { D’Amigo \& Gautier, } 2000\end{array}$} & \multicolumn{2}{|l|}{$\begin{array}{l}\text { Yasuni (Ecuator) } \\
\text { Balslev et al., } 1987\end{array}$} & \multicolumn{2}{|c|}{$\begin{array}{l}\text { Jenera Herrera (Peru) } \\
\text { Spichiger et al., } 1996\end{array}$} \\
\hline Famille & FIV & Famille & FIV & Famille & FIV & Famille & FIV \\
\hline Sapotaceae & 34.15 & Clusiaceae & 40.78 & Arecaceae & 55.66 & Leguminasae & 29.07 \\
\hline Leguminosae & 32.27 & Euphorbiaceae & 29.09 & Moraceae & 36.48 & Sapotaceae & 28.22 \\
\hline Burseraceae & 24.83 & Myrtaceae & 27.17 & Leguminasae & 23.73 & Moraceae & 23.50 \\
\hline Euphorbiaceae & 18.88 & Rubiaceae & 21.23 & Bombacaceae & 19.66 & Myristicaceae & 18.84 \\
\hline Meliaceae & 18.70 & Myristicaceae & 19.04 & Myristicaceae & 19.59 & Lauraceae & 18.28 \\
\hline Sterculiaceae & 18.57 & Lauraceae & 16.32 & Rubiaceae & 14.73 & Chrysobalanaceae & 18.05 \\
\hline Ebenaceae & 15.49 & Burseraceae & 13.77 & Meliaceae & 11.62 & Lecithidaceae & 17.38 \\
\hline Clusiaceae & 14.85 & Sapotaceae & 10.48 & Euphorbiaceae & 8.15 & Burseraceae & 11.84 \\
\hline Olcaceae & 13.51 & Erythroxylaceae & 9.51 & Cecropiaceae & 7.86 & Annonaceae & 10.67 \\
\hline Chrysobalanaceae & 12.08 & Annonaceae & 9.37 & Lecythidaceae & 7.54 & Arecaceae & 9.47 \\
\hline Flacourtiaceae & 11.91 & Sarcolaenaceae & 8.27 & Lauraceae & 7.37 & Vochysiaceae & 9.43 \\
\hline Combretaceae & 8.75 & Asteraceae & 8.22 & Sterculiaceae & 6.72 & Humiraceae & 8.52 \\
\hline Lecythidaceae & 6.64 & Leguminosae & 7.71 & Flacourtiaceae & 6.18 & Cecropiaceae & 7.89 \\
\hline Irvingiaceae & 6.37 & Ebenaceae & 7.57 & Polygonaceae & 6.07 & Rubiaceae & 7.79 \\
\hline Scytopetalaceae & 6.35 & Arecaceae & 7.17 & Sapotaceae & 5.59 & Combretaceae & 7.50 \\
\hline \multicolumn{2}{|c|}{$\begin{array}{l}\text { Alto Parana (Paraguay) } \\
\text { Spichiger et al., } 1992\end{array}$} & \multicolumn{2}{|c|}{$\begin{array}{l}\text { Alto Ivon (Bolivia) Boom, } \\
1986 \text { (Submountain going } \\
\text { up in lower highlander }\end{array}$} & \multicolumn{2}{|l|}{$\begin{array}{l}\text { Bahia (Brazil) } \\
\text { Mori et al., } 1983\end{array}$} & & \\
\hline Famille & FIV & Famille & FIV & Famille & FIV & & \\
\hline Meliaceae & 44.4 & Moraceae & 53.3 & Myrtaceae & 52.2 & & \\
\hline Lauraceae & 42.4 & Myristicaceae & 41.1 & Sapotaceae & 39.4 & & \\
\hline Sapotaceae & 39.4 & Palmae & 35.7 & Caesalpiniaceae & 28.5 & & \\
\hline Leguminosae & 31.9 & Leguminosae & 30.1 & Lauraceae & 20.8 & & \\
\hline Rutaceae & 25.4 & Melastomataceae & 20.1 & Chrysobalanaceae & 15.4 & & \\
\hline Moraceae & 20.4 & Cecropiaceae & 15.3 & Euphorbiaceae & 12.1 & & \\
\hline Boraginaceae & 14.7 & Vochysiaceae & 13.9 & Bombacaceae & 11.9 & & \\
\hline Arecaceae & 11.1 & Annonaceae & 8.7 & Lecythidaceae & 9.5 & & \\
\hline Annonaceae & 10.1 & Chrysobalanaceae & 8.3 & Melastomataceae & 9.4 & & \\
\hline Bignoniaceae & 8.2 & Rubiaceae & 8.3 & Moraceae & 9.4 & & \\
\hline Solanaceae & 4.6 & Lauraceae & 7.2 & & & & \\
\hline Myrtaceae & 3.5 & Burseraceae & 6.8 & & & & \\
\hline Sapindaceae & 3.2 & Euphorbiaceae & 5.7 & & & & \\
\hline Flacourtiaceae & 2.7 & Flacourtiaceae & 5.2 & & & & \\
\hline Euphorbiaceae & 2.5 & Myrtaceae & 4.5 & & & & \\
\hline
\end{tabular}


Specific level - In the present study 40 species were encountered. The number of species per hectare seems to be fluctuating in Africa (47-178) (Table 10), in Madagascar: 38-146 (Rakotomalaza and Messmer, 1999; Rabevohitra et al., 1996) and in the néotropical region: 94 at Alto Ivon (Bolivia) (Boom, 1986), 228 in Amazonian Ecuador (Balslev et al., 1987). Lower diversity values were recorded in Côte-d'Ivoire where Corthay (1996) found 76 and 77 species/ha in two plots in the Yapo forest and in Alto Parana where Spichiger et al. (1992) found 60 species. The Manengouba forest ( 40 species/ha) is characterized by the lowest value of number of species per hectare recorded by different researchers through the African, Madagascar and Neotropical (capital). forests. The selective conditions of the mesologic factors in the mountain effectively limit the number of plant species.

Table 10. Number of species per hectare and Shannon diversity index of Guinean-Congolese rainforests, in decreasing density.

\begin{tabular}{|l|l|l|c|c|}
\hline & Countries & References & $\begin{array}{l}\text { Number } \\
\text { species/ha }\end{array}$ & $\begin{array}{l}\text { Shannon } \\
\text { diversity index }\end{array}$ \\
\hline Kala forest & Cameroon & Madiapevo, 2008 & 178 & 5.19 \\
\hline Messa forest & Cameroon & Tagne, 2007 & 151 & 6.24 \\
\hline $\begin{array}{l}\text { Dja Forestry Reserve } \\
\text { (Djolimpoum L1) }\end{array}$ & Cameroon & Sonké, 1998 & 138 & 5.62 \\
\hline Lopé (site 4) & Gabon & White, 1992 & 129 & 4.14 \\
\hline Scio Classified Forest & Côte-d'Ivoire & $\begin{array}{l}\text { Nusbaumer et al., } \\
\text { 2005 }\end{array}$ & 89 & 5.91 \\
\hline Kouoghap Sacral Forest & Cameroon & Noumi, 2012 & 79 & 4.83 \\
\hline Yapo Classified Forest & Côte-d'Ivoire & Corthay, 1996 & 77 & 6.19 \\
\hline $\begin{array}{l}\text { Ngotto,forest } \\
\text { Cleistopholis patens } \text { and Ficus } \\
\text { mucuso forest }\end{array}$ & Republic & Lejoly, 1995 & 58 & 5.3 \\
\hline $\begin{array}{l}\text { Odzala National Park (Mbandza } \\
\text { 1) }\end{array}$ & Congo & Sokpon, 1995 & 53 & 4.76 \\
\hline Manengouba forest & Cameroon & Present study & 40 & 3.98 \\
\hline
\end{tabular}

According to Rollet (1983) an average of 50\% of individuals are represented by 20 species in undisturbed lowland Amazonian forests of Venezuela. In Manongarivo, half of the trees are represented by only 11 species. In Manegouba $53 \%$ of trees are represented only by 4 species and $63.9 \%$ by 5 species. These plant species are among the ten first in FIV due to their relative density. In high altitude numerous plants are gregarious.

The Shannon diversity index $\left(H^{\prime}\right)$ (Shannon and Weaver, 1949) permits a good approach of the diversity on the different plots because it takes into account the number of species and the distribution of abundances. Its calculated values for different Guinean forests are between 4 and 6.5. The Manengouba formation presents a low value $\left(H^{\prime}=3.98\right)$, which shows a less diversified forest, with gregarious species (Table 10). 
Mori et al. (1983) consider species found only once in the sample as rare. In a lowland forest of eastern Brazil $41 \%$ species were rare, according to this definition. A forest inventory in Andohahela, Madagascar (Rakotomalaza and Messmer, 1999) recorded a value of $38.8 \%$. In our study, the percentage of species represented by only one individual (32.5\%) is lower than those reported in the above mentioned studies and is close to the value reported in Messa $28 \%$ - (Tagne, 2007), but higher than -21.1\%- (D'Amico \& Gautier, 2000) in Manongarivo; $21.1 \%$ - (D'Amigo and Gautier, 2000), - $22 \%$ - (Spichiger et al., 1992) in Alto Parana and $12,5 \%$ - (Madiapevo, 2008) in Kala.

The ratio of individual/species in the 1-ha plot of Menengouba mountain is 18.65. In other 1-ha plots in Madagascar, recorded values were 6.1 (Rakotomalaza and Messmer, 1999) and 9.17 to 22.1 (Rabevohitra et al., 1996). In Cameroon the individual/species ratios found in the sub mountain forest are -8.03- Tagne (2007) and -10.05 - Madiapevo (2008). A series of 1-hectare forest inventories sampled in the neotropics recorded the following values: 8.42 in Southern Bahia, Brazil (Mori et al., 1983); 2.05 in Jenaro Herrera (Spichiger et al., 1996).

The IVI of Macaranga occidentalis, the species with the highest value in the plot, is 37.35 . Similar values were recorded in a gallery forest of Mogi-Guaçu, Brazil (Spichiger et al., 1996). where the highest IVIs were 37.7 and 43.5. These values fall to the 12.5-28.7 range of highest IVI recorded by Mori \& Boom(1987) in the lowland moist forests (Baslev et al., 1987); to -20.71- (Madiapevo, 2008) at Kala forest and to -16.37- (Tagne, 2007) at Messa forest.

Altitudinal affinities-Comparing floristic composition of Manengouba forest and other highlander rainforests sampled in Cameroon (Letouzey, 1985), 13 (38.46\%) species are shared with mountain vegetations: 10 species (Carapa grandiflora, Schefflera barteri, Schefflera mannii, Rothmannia urcelliformis, Prunus Africana, Bersama abyssinica, Rapanea melanophloeos, Allophylus bullatus, Gnidia glauca and Maytenus acuminata) in the mountain rainforests and 5 species (Polyscias fulva, Macaranga occidentalis, Maesa lanceolata, Alangium chinense and Vernonia blumeoides) in the secondary mountain forests. It is worth mentioning that among Leguminosae, widely abundant in all Guinean-Congolese region (Lowlander formations of divers types and submontain forests) (Letouzey, 1968, 1985), no species was shared between Manengouba highlander rainforest and lower altitude forests.

The phytogeographic affinities. According to White (1983) the Cameroonian mountains form an archipelago connected comfortably, at the floristic point of view, to the other African highlanders' archipelagos. The phytogeographic affinities of the mountain species recorded here falls within many distribution patterns.

Size of plant species, $20 \%$ of total species (Alangium chinense, Bersama abyssinica, Carapa grandiflora, Macaranga occidentalis, Polyscias fulva, Rothmannia urcelliformis, Schefflera barteri and Vernonia blumeoides) are widely distributed in Guinean-Congolese region forest; among which Alangium chinense has a paleotropical distribution (Jaques-Félix, 1970); 5\% of the species (Prunus africana and Rapanea melanophloeos ) are distributed throughout 3 African archipelagos (Cameroonian Afro-highlander archipelago, eastern Africa highlander archipelago and southern Africa highlander archipelago), 5\% of the species (Gnidia glauca and Maytenus acuminata) are shared only with the eastern Africa highlander 
Archipelago and 2.5\% (Maesa lanceolata) with southern Africa highlander Archipelago and 5\% (Allophylus bullatus and Schefflera mannii) are endemic of the Cameroonian highlander archipelago (Letouzey, 1985).

\section{Conclusion}

Based on the structure and composition at the family level, the Manengouba forest sampled in this study is clearly best classified as dense humid highlander rainforest. In comparison with Cameroonian sub mountain forests and other tropical lowland rainforests in the world, it displays the same relative values for tree densities together with an average number of rare species, a relatively high value for basal area, a relatively lower diversity.

The difference is well marked on the qualitative point of view where the Leguminosae family, important in the lower and sub mountain forests, is absent in the Manengouba forest. There, the family of Rubiaceae marks the altitudinal steep, by its importance.

Floristic affinities of the species show that more than 13 of species are orophytes among which some are widely distributed in the Guinean-Congolese region, whereas others are shared with the African eastern and southern archipelagos. There is also a clear component of Cameroonian mountains archipelago in which is located the Manengouba rainforest.

\section{References}

Aubréville, A., J. F. Leroy, \& G. Flore. (1963-1998). Flora of Cameroon, Vol 1 to 34. National Museum of Natural History, Laboratory of the Phanerogames, Paris.

Balslev, H. J., B. Luteyn, L. B. Ollgaard, \& Holm-Nielsen. (1987). Composition and structure of adjacent unflooded and floodplain forest in Amazonian Ecuator". Opera Bot. 92, 37-57.

Boom, B. M. (1986). A Forest inventory in Amazonian Boliva. Biotrop. 18, 287-294. http://dx.doi.org/10.2307/2388571

Colinvaux, P. (1986). Ecology. Wiley \& Sons, New York, p. 725.

Collin, C. (1998). Study of the biodiversity of the woody plants of the Ndote forest (Equatorial Guinea). End of study work, Free University of Brussels,. Lab. Syst. Bot. Phytosociol., p. 79.

Corthay, R. (1996). Floristic analysis of the Yapo rainforest (Côte d'Ivoire). Diploma thesis, University of Geneva.

Cottam, G., \& J. T. Curtis. (1956). The use of distance measures in phytosociological sampling. Ecology 37, 451-460. http://dx.doi.org/10.2307/1930167

D'Amico, C., \& L. Gautier. (2000). Inventory of a 1-ha lowland rainforest plot in Manongarivo (NW Madagascar). Candollea, 55, 319-340.

Deruelle, B. C., C. Moreau, R. Nkoumbou, J. Kambou, E. Lissom, R. T. Njonfang, A. Ghogomu, \& Nono. (1991). The Cameroon Line: a review in Magmatism in extensional structural settings. The phanerozoic African plate. KAMPUnZU AB and LuBALA RT (eds) Springer, Berlin, Germany. Pp 274-327. 


\section{Macrothink}

Journal of Biology and Life Science ISSN 2157-6076 2013, Vol. 4, No. 2

Gentry, A. H. (1982). Patterns of neotropical plant species diversity. Evol. Biol. 15, 1-84. http://dx.doi.org/10.1007/978-1-4615-6968-8_1

Gentry, A. H. (1988). Changes in plant community diversity and floristic composition on environmental and geographical gradients. Ann. Missouri Bot. Gard., 75, 1-34. http://dx.doi.org/10.2307/2399464

Gesnot, K. (1994). Forest inventory in the bees forest (Gabon). End of study Work, Free University of Brussels, p. 108.

Gounot, M. (1969). Quantitative Method of vegetation survey. Masson and Company, Paris, p. 314.

Hutchinson J., \& J. M. Dalziel. (1954-1972). Flora of West Tropical Africa. Vol. 1-3. Milbank, London, England

Jacques-Félix, H. (1970). Ombellales. Flora of Cameroon 10. MESRES, Yaoundé, Cameroon, p. 108.

Kagou, D. A. (1998). Volcanological, petrographical and geochemical survey of a polygenic strato - volcano of the line of Cameroon: the Mount Manengouba (Province of Littoral and the Southwest, Cameroon). Thesis Doctorate 3rd cycle, University of Yaoundé I, Yaoundé, Cameroon.

Lebrun, J., \& G. Gilbert. (1954). An ecological classification of the Belgian Congo forests. Publ. I.N.E.A.C., Ser. Sci., 63, 101 p..

Lebrun, J. P. S., \& A. L. Stork. (1191, 1992, 1995, 1997). Induction of the flowering plants of tropical Africa, 4 volumes. Editions of the Conservatories and Garden Botanies of the city of Geneva, Switzerland.

Lejoly, J. (1995). Use of the transect method in the survey of biodiversity in the conservation zone of the Ngotto forest Centrafrican Republic. Technic repport. Ecofac, Agreco-CTFT project, p. 114.

Letouzey, R. (1968). Phytogeographic study of Cameroon. Edit. P. Lechevalier, Paris, p. 511.

Letouzey, R. (1985). Note of the phytogeograhic map of Cameroon at 1/500000. I.R.A. Yaoundé, p. 240.

Madiapevo, S. N. (2008). Study of the diversity and the structure of the woody plant of the submountain forest of the Kala mount $(1156 \mathrm{~m})$, region of Yaoundé. Memory of DEA, University of Yaoundé I, p. 71.

Mohandass, D., \& P. Davidar. (2009). Floristic structure and diversity of a tropical montane evergreen forest (shola) of the Nilgiri Mountains, Southern India. Tropical Ecology, 50(2), 219-229.

Mori, S. A., \& B. M. Boom. (1987). The Lecytidaceae of a lowland Neotropical forest, La Fumée mountain, French Guinea, chapter II. The forest. Mem. New York Bot. Garden 44, 9-29. 
Mori, S. A., B. M. Boom, A. M. Carvalho, \& T. S. Dos Santos (1983). Ecological importance of Myrtaceae in an Eastern Brazilian wet forest. Biotrop. 15, 68-70. http://dx.doi.org/10.2307/2388002

Normand, M. D. (1965). Identification of the trees and the woods of the main forest species in the Centrafrican Republic. C.T.F.T. Nogent-sur-Marne, p. 78.

Noumi, E. (1998). The " Transition Forest " of Garcinia spp. of the Nkolobot hills (Region of Yaoundé, Cameroon). Belg. J. Bot., 130(2), 198-220.

Noumi. E. (2012). Ligneous flora diversity of a submountain forest of west Cameroon; the Kouoghap sacral forest of the village Batoufam. J. Ecol. Nat. Env., 4(1), 8-28.

Nusbaumer, L., L. Gautier, C. Chatelin, \& R. Spichiger. (2005). Floristic structure and composition of the classified forest of the Scio (Côte d'Ivoire). Descriptive and comparative study. Candollea, 60(2), 393-443.

Piélou, E. C. (1966). Species diversity and Pattern diversity in study of ecological succession. $J$. Theor. Biol., 10, 370-383. http://dx.doi.org/10.1016/0022-5193(66)90133-0

Rabevohitra, R., P. P. Lowry II, H. Randrianjafy, G. E. Schatz, \& N. Razafindrianilana. (1996). Assessment of plant diversity and conservation importance of East Coast Low Elevation Malagasy Rain forests. Report on the project: National center of Research applied to the Farming development, Madagascar. Department of forest and piscicoles research, Madagascar. Biodiversity support program. Missouri Botanica Garden. St Louis.

Rakotomalaza, P. I., \& N. Messmer. (1999). Structural and floristic composition of the vegetation in the Reserve natural integral of Andohahela of Andohahela, Madagascar. In: goodman SM (ed.). A floral and faunal inventory of the Reserve natural integral of Andohahela, Madagascar: with reference to elevational variation. Fieldiana Zoology, new series, 94. 51-96.

Raunkiaer, C. (1934). The life forms of plants and statistical plant geography. Clarendron Press, Oxford, England, p. 632.

Reitsma, J. M. (1988). Forest vegetation of Gabon. The Tropenbos foundation, Ede, Netherlands, p. 142.

Rolle, B. (1979). Application of various methods of analyses of data to detailed forest inventories raised in tropical forest. Oecol. Plant, 14(3), 319-344.

Rollet, B. (1983). The natural regeneration in the openings. A general process of the dynamics of the humid tropical forests. Woods and Forests of the Tropics 201, 3-34.

Schnell, R. (1970). Introduction to the phytogeography of the tropical countries: the general problems 1. Gauthier-Villars, Paris, p. 499.

Senterre, B., J. Lejoly, \& B. Sonké. (2004). Analysis of the pressure gradient of continentality and identification of plant communities in rainforests of central Africa by the method of the $\begin{array}{llll}\text { mega } & \text { transect. } & \text { Phytocoenologia, } & \text { 34(3). }\end{array}$ http://dx.doi.org/10.1127/0340-269X/2004/0034-0491 


\section{Macrothink}

Senterre, B. (2005). Methodological research for the typology of the vegetation and the phytogeography of the tropical Africa rainforests. Doctorate thesis,in Agro.Sc. and Biol. engineering. Free University of Brussels, p. 347.

Shannon C. E. \& W. Weaver (1949). The mathematical theory of communication. Urbana Univ. Press, Illinois, 117-127.

Sokpon, N. S. (1995). Ecological research on the moist semi-deciduous forest of the Cleistopholis patens and Ficus mucuso forest in the South-East of Benin: plant groupings, natural regeneration and fall of the litter. Thesis of Doctorate, Free University of Brussels, Belgium, p. 350.

Sonke, B. (1998). Floristic and structural studies of the Dja reserve of fauna forests (Cameroon). Doctorate thesis of the free University of Brussels, p. 267

Spichiger, R., B. S. Bertoni, \& P. A. Loizeau. (1992). The forest of Alto Parana. Candollea, 47: 219-250 .

Spichiger, R., P. A. Loizeau, C. Latou, \& G. Barriera. (1996). Tree species richness of South-Western Amazonian forest (Jenero Herrera, Peru, 7340’W/454'S). Candollea, 51, 559-577.

Tagne, T. G. A. (2007). Floristic and structural study of the ligneous flora of the submountain forest of the Messa hill (Yaoundé). Memory of DEA thesis, University of Yaoundé I, p. 66.

Van Asbroeck, P. (1997). Survey of the plant biodiversity of the woody in the forest of the National Park of Odzola (Republic of Congo). End of study work. Lab. Syst. Bot. Phytosociol., Free University of Brussels, Brussels, Belgium, p. 107.

Van Reeth, L. (1997). Analysis of the biodiversity of the ligneous flora in the National park of Monte Alén in Équatorial Guinea. End of study work, Free University of Brussels, Lab. Syst. Bot. Phytosociol., p. 119.

Villanueva, A. G. (1991). Quantitative and structural assessment of a humid tropical forest in view of its forest in Iquitos-Peru. Thesis of doctorate, Catholic University of Louvain, Louvain, Belgium, p. 181.

Vivien, J., \& J. J. Faure. (1985). Trees in dense forests of Central Africa. ACCT, Paris, p. 565.

White, F. (1983). The vegetation of Africa. A descriptive memory to accompagny the UNESCO/AETFAT/UNSO vegetation map of Africa. Natural Resources Research 20, UNESCO, Paris, P. 356.

White, J. T. L. (1992). Vegetation history and logging disturbance: Effects on rain forest mammals in the Lopé reserve, Gabon (with special emphasis on elephants and apes). Ph.D. thesis, University of Edinburg, Edingburg, p. 250.

Yahmed, D. B., \& N. Houstin. (2006). Atlas of Africa, Cameroon. Jeune Afrique Editions, Paris, P. 135. 


\section{Macrothink $\Delta$ Institute ${ }^{m}$}

Journal of Biology and Life Science

ISSN 2157-6076

2013, Vol. 4, No. 2

Appendix 2. Density, basal area, diversity and FIV of the plant families encountered in the 1-ha

Manengouba plot, presented by decreasing FIV.

\begin{tabular}{|c|c|c|c|c|c|c|c|c|}
\hline $\mathrm{N}^{\circ}$ & Families & $\begin{array}{c}\text { Number of } \\
\text { species }\end{array}$ & $\begin{array}{c}\text { Number } \\
\text { of trees }\end{array}$ & $\begin{array}{c}\text { Basal } \\
\text { area }\left[\mathrm{m}^{2}\right]\end{array}$ & $\begin{array}{c}\text { Relative } \\
\text { diversity } \\
{[\mathrm{x} 100 \%]}\end{array}$ & $\begin{array}{c}\text { Relative } \\
\text { density } \\
{[\mathrm{x} 100 \%]}\end{array}$ & $\begin{array}{c}\text { Relative } \\
\text { dominance } \\
{[\mathrm{x} 100 \%]}\end{array}$ & $\begin{array}{c}\text { FIV } \\
{[\mathrm{x} 300 \%]}\end{array}$ \\
\hline 1 & Rubiaceae & 6 & 196 & 9.57 & 15 & 25.69 & 15.50 & 56.19 \\
\hline 2 & Euphorbiaceae & 6 & 114 & 15.91 & 15 & 14.94 & 25.77 & 55.71 \\
\hline 3 & Araliaceae & 4 & 91 & 17.97 & 10 & 11.93 & 29.11 & 51.03 \\
\hline 4 & Myrsinaceae & 2 & 217 & 9.93 & 5 & 28.44 & 16.08 & 49.52 \\
\hline 5 & Meliaceae & 2 & 40 & 3.59 & 5 & 5.24 & 5.81 & 16.06 \\
\hline 6 & Moraceae & 3 & 4 & 0.19 & 7.5 & 0.52 & 0.31 & 8.33 \\
\hline 7 & Rutaceae & 2 & 11 & 0.93 & 5 & 1.44 & 1.51 & 7.95 \\
\hline 8 & Cyatheaceae & 2 & 15 & 0.27 & 5 & 1.97 & 0.44 & 7.40 \\
\hline 9 & Opiliaceae & 1 & 19 & 1.03 & 2.5 & 2.49 & 1.67 & 6.66 \\
\hline 10 & Sapindaceae & 2 & 6 & 0.25 & 5 & 0.79 & 0.40 & 6.19 \\
\hline 11 & Thymelaeaceae & 1 & 19 & 0.37 & 2.5 & 2.49 & 0.60 & 5.59 \\
\hline 12 & Rosaceae & 1 & 10 & 0.82 & 2.5 & 1.31 & 1.33 & 5.14 \\
\hline 13 & Melianthaceae & 1 & 8 & 0.44 & 2.5 & 1.05 & 0.71 & 4.26 \\
\hline 14 & Asteraceae & 1 & 4 & 0.07 & 2.5 & 0.52 & 0.11 & 3.14 \\
\hline 15 & Alangiaceae & 1 & 2 & 0.21 & 2.5 & 0.26 & 0.34 & 3.10 \\
\hline 16 & Oleaceae & 1 & 3 & 0.08 & 2.5 & 0.39 & 0.13 & 3.02 \\
\hline 17 & Capparaceae & 1 & 1 & 0.05 & 2.5 & 0.13 & 0.08 & 2.71 \\
\hline 18 & Celastraceae & 1 & 1 & 0.02 & 2.5 & 0.13 & 0.03 & 2.66 \\
\hline 19 & Chrysobalanace & 1 & 1 & 0.02 & 2.5 & 0.13 & 0.03 & 2.66 \\
\hline 20 & aauraceae & 1 & 1 & 0.02 & 2.5 & 0.13 & 0.03 & 2.66 \\
\hline & Total & 40 & 763 & 61.74 & 100 & 100 & 100 & 300 \\
\hline
\end{tabular}

Appendix 3. Density, basal area, frequency and IVI of the species of the Manengouba 1-ha plot, presented by decreasing IVI.

\begin{tabular}{|r|l|r|r|r|r|r|r|r|}
\hline $\mathrm{N}^{\circ}$ & \multicolumn{1}{|c|}{ Species } & $\begin{array}{l}\text { Absolute } \\
\text { frequency }\end{array}$ & $\begin{array}{l}\text { Number } \\
\text { of trees }\end{array}$ & $\begin{array}{l}\text { Basal } \\
\text { area } \\
{\left[\mathrm{m}^{2}\right]}\end{array}$ & $\begin{array}{l}\text { Relative } \\
\text { Frequen } \\
\mathrm{cy} \\
{\left[\begin{array}{l}{[\mathrm{x}} \\
100\end{array}\right.}\end{array}$ & $\begin{array}{l}\text { Relative } \\
\text { density } \\
{[\mathrm{x}} \\
100 \%]\end{array}$ & $\begin{array}{l}\text { Relative } \\
\text { Dominance } \\
{[\mathrm{x} 100 \%]}\end{array}$ & $\begin{array}{c}\text { IVI } \\
{[\mathrm{x} 300 \%]}\end{array}$ \\
\hline 1 & Macaranga occidentalis & 6 & 93 & 12.75 & 4.51 & 12.19 & 20.65 & 37.35 \\
\hline 2 & Rapanea melanophloeos & 10 & 124 & 4.14 & 7.52 & 16.25 & 6.71 & 30.48 \\
\hline 3 & Maesa lanceolata & 6 & 93 & 5.79 & 4.51 & 12.19 & 9.38 & 26.08 \\
\hline 4 & Polyscias fulva & 10 & 25 & 8.25 & 7.52 & 3.28 & 13.36 & 24.16 \\
\hline 5 & psydrax arnoldianum & 6 & 95 & 4 & 4.51 & 12.45 & 6.48 & 23.44 \\
\hline 6 & $\begin{array}{l}\text { Rothmannia } \\
\text { urcelliformis }\end{array}$ & 5 & & & & & & \\
\hline 7 & Schefflera barteri & 4 & 34 & 7.03 & 3.01 & 4.46 & 11.39 & 18.85 \\
\hline
\end{tabular}




\begin{tabular}{|c|c|c|c|c|c|c|c|c|}
\hline 8 & Carapa grandiflora & 5 & 27 & 2.68 & 3.76 & 3.54 & 4.34 & 11.64 \\
\hline 9 & Schefflera mannii & 8 & 10 & 2 & 6.02 & 1.1 & 3.24 & 10.57 \\
\hline 10 & Croton macrostachyus & 6 & 15 & 2.06 & 4.51 & 1.97 & 3.34 & 9.81 \\
\hline 11 & Opilia celtidifolia & 7 & 19 & 1.03 & 5.26 & 2.49 & 1.67 & 9.42 \\
\hline 12 & Schefflera abyssinica & 4 & 22 & 0.69 & 3.01 & 2.88 & 1.12 & 7.01 \\
\hline 13 & Prunus africana & 5 & 10 & 0.82 & 3.76 & 1.31 & 1.33 & 6.40 \\
\hline 14 & Gaertnera paniculata & 4 & 9 & 0.65 & 3.01 & 1.18 & 1.05 & 5.24 \\
\hline 15 & Zanthoxylum & 3 & & & & & & \\
\hline & Xanthoxylö̈des & & 8 & 0.88 & 2.26 & 1.05 & 1.43 & 4.73 \\
\hline 16 & Carapa procera & 2 & 13 & 0.91 & 1.50 & 1.70 & 1.47 & 4.68 \\
\hline 17 & Gnidia glauca & 2 & 19 & 0.37 & 1.50 & 2.49 & 0.60 & 4.59 \\
\hline 18 & Cremaspora triflora & 4 & 7 & 0.12 & 3.01 & 0.92 & 0.19 & 4.12 \\
\hline 19 & Bersama abyssinica & 3 & 8 & 0.44 & 2.26 & 1.05 & 0.71 & 4.02 \\
\hline 20 & Cyathea manniana & 2 & 14 & 0.25 & 1.50 & 1.83 & 0.40 & 3.74 \\
\hline 21 & Vernonia blumeoides & 4 & 4 & 0.07 & 3.01 & 0.52 & 0.11 & 3.65 \\
\hline 22 & Sclerocroton ellipticus & 2 & 3 & 1.01 & 1.50 & 0.39 & 1.64 & 3.53 \\
\hline 23 & $\begin{array}{l}\text { Chionanthus mannii } \\
\text { (subsp. congesta }\end{array}$ & 4 & 3 & 0.08 & 3.01 & 0,39 & 0.13 & 3.53 \\
\hline 24 & Teclea afzelii & 3 & 3 & 0.05 & 2.26 & 0.39 & 0.08 & 2.73 \\
\hline 25 & Allophylus bullatus & 2 & 5 & 0.23 & 1.50 & 0.66 & 0.37 & 2.53 \\
\hline 26 & Alangium chinense & 2 & 2 & 0.21 & 1.50 & 0.26 & 0.34 & 2.11 \\
\hline 27 & Ficus elasticoides & 1 & 2 & 0.15 & 0.75 & 0.6 & 0.24 & 1.26 \\
\hline 28 & Bridelia speciosa & 1 & 1 & 0.05 & 0.75 & 0.13 & 0.08 & 0.96 \\
\hline 29 & Euadenia trifoliolata & 1 & 1 & 0.05 & 0.75 & 0.13 & 0.08 & 0.96 \\
\hline 30 & Rothmannia hispida & 1 & 1 & 0.05 & 0.75 & 0.13 & 0.08 & 0,6 \\
\hline 31 & $\begin{array}{l}\text { Antidesma laciniatum } \\
\text { var. laciniatum }\end{array}$ & 1 & 1 & 0.02 & 0.75 & 0.13 & 0.03 & 0.92 \\
\hline 32 & Bertiera laxa & 1 & 1 & 0.02 & 0.75 & 0.13 & 0.03 & 0.92 \\
\hline 33 & Bridelia micrantha & 1 & 1 & 0.02 & 0.75 & 0.13 & 0.03 & 0.92 \\
\hline 34 & Cyathea camerooniana & 1 & 1 & 0.02 & 0.75 & 0.13 & 0.03 & 0.92 \\
\hline 35 & Dactyladenia lehmbachii & 1 & 1 & 0.02 & 0.75 & 0.13 & 0.03 & 0.92 \\
\hline 36 & Ficus sur & 1 & 1 & 0.02 & 0.75 & 0.13 & 0.03 & 0.92 \\
\hline 37 & Haplocoelum gallaense & 1 & 1 & 0.02 & 0.75 & 0.13 & 0.03 & 0.92 \\
\hline 38 & Maytenus acuminata & 1 & 1 & 0.02 & 0.75 & 0.13 & 0.03 & 0.92 \\
\hline 39 & Milicia excelsa & 1 & 1 & 0.02 & 0.75 & 0.13 & 0.03 & 0.92 \\
\hline \multirow[t]{2}{*}{40} & Persea americana & 1 & 1 & 0.02 & 0.75 & 0.13 & 0.03 & 0.92 \\
\hline & Total & 133 & 763 & 61.74 & 100 & 100 & 100 & 300 \\
\hline
\end{tabular}

Appendix 1. Floristic list of the highlander Manengouba forest (Mbouroukou, northeast side) with the number of individuals by class of diameter and woody species frequency, counted on the 1 ha-sampling by 10 plots. 


\section{Macrothink Anstitute ${ }^{\mathrm{m}}$}

Journal of Biology and Life Science

ISSN 2157-6076

2013, Vol. 4, No. 2

\begin{tabular}{|c|c|c|c|c|c|c|c|c|c|c|c|c|c|c|c|c|c|c|}
\hline & & & & & & & \multicolumn{12}{|c|}{ Number of individual encountered in 1-ha plot by diameter classes $(\mathrm{cm})$} \\
\hline $\mathrm{N}^{\circ}$ & Families & TB & VA & UP & Species & $\mathrm{F}$ & $\begin{array}{l}{[10-2} \\
0[\end{array}$ & {$[20-30$} & {$[30-40$} & $\begin{array}{l}{[40-5} \\
0[\end{array}$ & $\begin{array}{l}{[50-6} \\
0[\end{array}$ & $\begin{array}{l}60-7 \\
0[\end{array}$ & $\mid \begin{array}{l}70-8 \\
0[\end{array}$ & $\mid \begin{array}{l}{[80-9} \\
0[\end{array}$ & $\begin{array}{l}{[90-1} \\
00[\end{array}$ & $\begin{array}{l}{[100-} \\
110[\end{array}$ & $\left|\begin{array}{l}{[110-} \\
120[\end{array}\right|$ & $\begin{array}{l}\text { Total } \\
\text { trees }\end{array}$ \\
\hline 1 & Araliaceae & & & & Polyscias fulva (Hiern) Harms & 10 & 5 & 2 & 1 & 3 & 2 & 2 & 3 & 3 & 2 & 1 & 1 & 25 \\
\hline 2 & Meliaceae & Msph & $\mathrm{Mi}$ & Fic & Carapa grandiflora Sprague & 5 & 8 & 10 & 7 & & & 1 & & & & & 1 & 27 \\
\hline 3 & Araliaceae & Msph & $\mathrm{Mi}$ & Fic & Schefflera barteri (Seem.) Harms & 4 & 2 & 3 & 9 & 11 & 3 & 1 & 2 & 1 & & 2 & 2 & 34 \\
\hline 4 & Euphorbiaceae & Msph & $\mathrm{Mi}$ & Pol & Macaranga occidentalis Müll. Arg. & 6 & 14 & 24 & 18 & 12 & 18 & 2 & 3 & & 2 & & & 93 \\
\hline 5 & Araliaceae & Msph & $\mathrm{Mi}$ & $\begin{array}{l}\text { Fic, } \\
\text { End }\end{array}$ & Schefflera mannii (Hook. f.) Harms & 8 & 4 & 1 & 1 & & & 1 & 2 & 1 & & & & 10 \\
\hline 6 & Euphorbiaceae & Msph & $\mathrm{Mi}$ & Str & $\begin{array}{l}\text { Sclerocroton ellipticus Hochst. ex } \\
\text { Krauss }\end{array}$ & 2 & & & & & 1 & 1 & 1 & & & & & 3 \\
\hline 7 & Meliaceae & Msph & $\mathrm{Bm}+\mathrm{Sm}$ & Str & Carapa procera DC. & 2 & 7 & 2 & 2 & 1 & & 1 & & & & & & 13 \\
\hline 8 & Euphorbiaceae & Msph & $\mathrm{Sm}$ & Mus & Croton macrostachyus Hochst. ex Del. & 6 & & 2 & 7 & 3 & 2 & 1 & & & & & & 15 \\
\hline 9 & Rubiaceae & Mcph & $\mathrm{Mi}$ & Gar & Gaertnera paniculata Benth. & 4 & 4 & 3 & 1 & & & 1 & & & & & & 9 \\
\hline 10 & Myrsinaceae & Msph & $\mathrm{Mi}+\mathrm{Ms}$ & Pol & Maesa lanceolata Forssk. & 6 & 12 & 52 & 28 & & & 1 & & & & & & 93 \\
\hline 11 & Rutaceae & Msph & $\begin{array}{ll}\mathrm{Bm} \quad+ \\
\mathrm{Sm}\end{array}$ & Mus & $\begin{array}{l}\text { Zanthoxylum Xanthoxylö̈des (Lam.) } \\
\text { Waterman }\end{array}$ & 3 & & 4 & 2 & 1 & & 1 & & & & & & 8 \\
\hline 12 & Rubiaceae & Mcph & $\mathrm{Sm}$ & Fic & $\begin{array}{l}\text { Rothmannia } \quad \text { urcelliformis } \\
\text { Bull. ex Rob. }\end{array}$ & 5 & 32 & 27 & 18 & 4 & 2 & & & & & & & 83 \\
\hline 13 & Rosaceae & Msph & $\mathrm{Mi}$ & Fic & Prunus africana (Hook. f.) Kalkm. & 5 & 5 & 2 & & 1 & 2 & & & & & & & 10 \\
\hline 14 & Opiliaceae & Msph & $\begin{array}{l}\mathrm{Bm} \\
\mathrm{Sm}\end{array}$ & Gar & $\begin{array}{l}\text { Opilia celtidifolia (Guill. \& Perr.) } \\
\text { Endl. ex Walp. }\end{array}$ & 7 & 5 & 10 & 3 & 1 & & & & & & & & 19 \\
\hline 15 & Alangiaceae & Msph & $\mathrm{Mi}$ & Pol & Alangium chinense (Lour.) Harms & 2 & & 1 & & 1 & & & & & & & & 2 \\
\hline 16 & Rubiaceae & Msph & $\mathrm{Sm}$ & Gil & $\begin{array}{l}\text { psydrax arnoldianum (De Wild. \& Th. } \\
\text { Dur.) Hepper }\end{array}$ & 6 & 39 & 44 & 12 & & & & & & & & & 95 \\
\hline 17 & Melianthaceae & Msph & $\mathrm{Mi}$ & Fic & Bersama abyssinica Fresen & 3 & 3 & 2 & 3 & & & & & & & & & 8 \\
\hline 18 & Myrsinaceae & Msph & $\mathrm{Mi}+\mathrm{Ms}$ & Fic & Rapanea melanophloeos ( L.) Mez & 10 & 65 & 57 & 2 & & & & & & & & & 124 \\
\hline
\end{tabular}




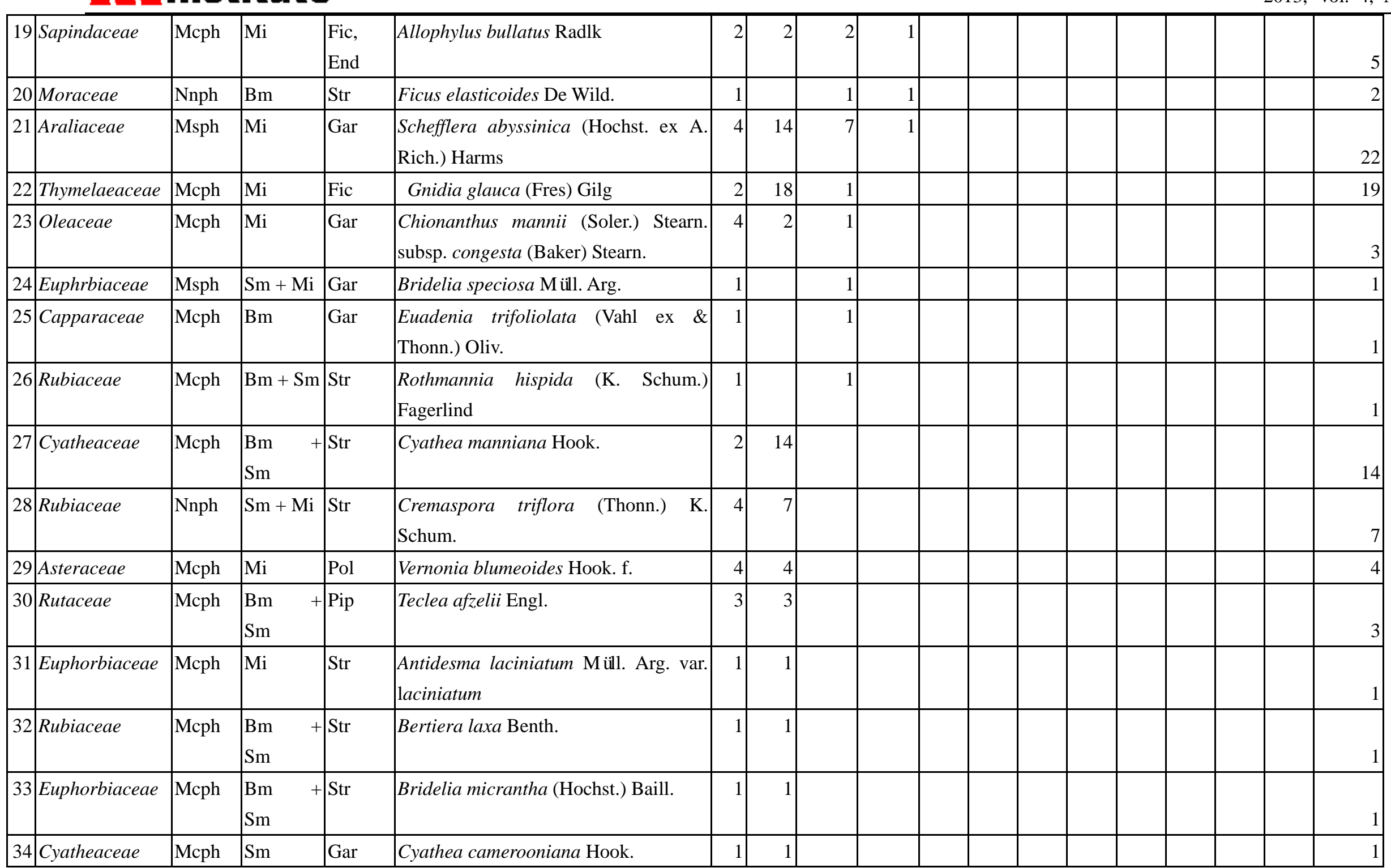




\section{Macrothink}

\begin{tabular}{|c|c|c|c|c|c|c|c|c|c|c|c|c|c|c|c|c|c|c|}
\hline 35 & $\begin{array}{l}\text { Chrysobalanace } \\
\text { ae }\end{array}$ & Nnph & $\begin{array}{ll}\mathrm{Bm} \\
\mathrm{Sm}\end{array}$ & Str & $\begin{array}{l}\text { Dactyladenia lehmbachii (Engl.) } \\
\text { Prance \& F. White }\end{array}$ & 1 & 1 & & & & & & & & & & & 1 \\
\hline 36 & Moraceae & Nnph & $\begin{array}{ll}\mathrm{Bm} & + \\
\mathrm{Sm} & \end{array}$ & Mus & Ficus sur Forssk. & 1 & 1 & & & & & & & & & & & 1 \\
\hline 37 & Sapindaceae & Mcph & $\begin{array}{ll}\mathrm{Bm} & + \\
\mathrm{Sm} & \end{array}$ & Mus & $\begin{array}{|ll|}\text { Haplocoelum gallaense } & \text { (Engl.) } \\
\text { Radlkofer } & \end{array}$ & 1 & 1 & & & & & & & & & & & 1 \\
\hline 38 & Celastraceae & Mcph & $\mathrm{Mi}$ & Fic & Maytenus acuminata (L. f.) Loes. & 1 & 1 & & & & & & & & & & & 1 \\
\hline 39 & Moraceae & Mcph & $\mathrm{Bm}$ & Str & Milicia excelsa (Welw.) C. C. Berg & 1 & 1 & & & & & & & & & & & 1 \\
\hline 40 & Lauraceae & Mcph & Cultiv & Mus & Persea americana Mill. & 1 & 1 & & & & & & & & & & & 1 \\
\hline 41 & Burseraceae & Mcph & $\begin{array}{ll}\mathrm{Bm} & + \\
\mathrm{Sm} & \end{array}$ & Str & $\begin{array}{l}\text { Dacryodes klaineana (Pierre) H. J. } \\
\text { Lam. }\end{array}$ & & & & & & & & & & & & & \\
\hline 42 & Leguminosae & Phgr & $\mathrm{Mi}$ & Fic & Milletia pilosa Hutch. \& Daziel & & & & & & & & & & & & & \\
\hline 43 & Convolvulaceae & Phgr & $\begin{array}{ll}\mathrm{Bm} & + \\
\mathrm{Sm} & \end{array}$ & Str & $\begin{array}{l}\text { Neuropeltis acuminata (P. Beauv.) } \\
\text { Benth. }\end{array}$ & & & & & & & & & & & & & \\
\hline 44 & Rubiaceae & Nnph & $\mathrm{Mi}$ & Fic & $\begin{array}{l}\text { Psychotria peduncularis } \quad \text { (Salisb.) } \\
\text { Steyerm. var. peduncularis }\end{array}$ & & & & & & & & & & & & & \\
\hline 45 & Rubiaceae & Nnph & $\mathrm{Sm}$ & Gar & Psychotria vogeliana Benth. & & & & & & & & & & & & & \\
\hline 46 & Annonaceae & Nnph & $\mathrm{Sm}$ & Gar & $\begin{array}{l}\text { Uvariodendron fuscum (Benth.) R. E. } \\
\text { Fries }\end{array}$ & & & & & & & & & & & & & \\
\hline 47 & Asteraceae & Nnph & $\mathrm{Mi}$ & Pol & Vernonia hymenolepis A. Rich. & & & & & & & & & & & & & \\
\hline & \multicolumn{5}{|c|}{ Total individuals } & 133 & 279 & 261 & 117 & 38 & 30 & 13 & 11 & 5 & 4 & 3 & 2 & 763 \\
\hline & Total basal area & & & & & & 4.93 & 12.81 & 11.26 & 6.04 & 7.13 & 4.31 & 4.86 & 2.84 & 2.84 & 2.60 & 2.08 & \\
\hline
\end{tabular}


Legend of appendix 1.

\begin{tabular}{|c|c|c|c|c|c|}
\hline BT & $\begin{array}{c}\text { Biological Types (BT) } \\
\text { Raunkiaer, 1934; } \\
\text { Schnell, 1970) }\end{array}$ & $\begin{array}{c}\mathrm{AV} \\
\text { code }\end{array}$ & $\begin{array}{l}\text { Altitudinal variation } \\
\text { (AV) (Senterre, (2005) }\end{array}$ & PU & $\begin{array}{l}\text { Phytosociological Units } \\
\text { (PU) }\end{array}$ \\
\hline Mcph & Microphanerophyte & $\mathrm{Bm}$ & $\begin{array}{l}\text { Lower and middle } \\
\text { altitudes }\end{array}$ & Fic & $\begin{array}{c}\text { Ficalhoeto-Podocarpetalia } \\
\text { Lebrun and Gilbert } 1954\end{array}$ \\
\hline Msph & Mesophanerophyte & $\begin{array}{c}\mathrm{Bm}+ \\
\mathrm{Sm}\end{array}$ & $\begin{array}{l}\text { Lower and middle } \\
\text { altitudes going up in Sm }\end{array}$ & Gar & Garcinietalia Noumi 1998 \\
\hline Nnph & Nanophanerophyte & Mi & $\begin{array}{c}\text { Lower highlander (strong } \\
\text { hygrometry) }\end{array}$ & Gil & $\begin{array}{c}\text { Gilbertiodendretalia } \\
\text { dewevrei Lebrun and } \\
\text { Gilbert } 1954\end{array}$ \\
\hline \multirow[t]{5}{*}{ Phgr } & Phanerophyte climbing & $\begin{array}{c}\mathrm{Mi}+ \\
\mathrm{Ms}\end{array}$ & $\begin{array}{l}\text { Lower highlander going up } \\
\text { in Ms }\end{array}$ & Mus & $\begin{array}{l}\text { Musango-Terminalietea } \\
\text { Lebrun and Gilbert } 1954\end{array}$ \\
\hline & & Ms & $\begin{array}{c}\text { Superior highlander (weak } \\
\text { hygrometry) }\end{array}$ & Pip & $\begin{array}{c}\text { Piptadeniastro-Celtidetalia } \\
\text { Lebrun and Gilbert } 1954\end{array}$ \\
\hline & & $\mathrm{Sm}$ & Submountain & Pol & $\begin{array}{c}\text { Polyscietalia fulvae } \\
\text { Lebrun and Gilbert } 1954\end{array}$ \\
\hline & & $\begin{array}{c}\mathrm{Sm}+ \\
\mathrm{Mi}\end{array}$ & $\begin{array}{c}\text { Submountain going up in } \\
\text { Mi }\end{array}$ & Str & $\begin{array}{l}\text { Strombosio-Parinarietea } \\
\text { Lebrun and Gilbert } 1954\end{array}$ \\
\hline & & & Cultiv. : species cultivated & End & $\begin{array}{c}\text { endemic to the } \\
\text { Cameroonian high } \\
\text { mountains archipelago", }\end{array}$ \\
\hline
\end{tabular}

\section{Copyright Disclaimer}

Copyright reserved by the author(s).

This article is an open-access article distributed under the terms and conditions of the Creative Commons Attribution license (http://creativecommons.org/licenses/by/3.0/). 